\title{
ANALYSIS OF THE PEAK-FLOW GAGING NETWORK IN NORTH DAKOTA
}

\section{By Tara Williams-Sether}

U.S. GEOLOGICAL SURVEY

Water-Resources Investigations Report 96-4178

Prepared in cooperation with the

NORTH DAKOTA DEPARTMENT OF TRANSPORTATION 


\title{
U.S. DEPARTMENT OF THE INTERIOR BRUCE BABBITT, Secretary
}

\author{
U.S. GEOLOGICAL SURVEY \\ GORDON P. EATON, Director
}

Any use of trade, product, or firm names is for descriptive purposes only and does not imply endorsement by the U.S. Government.

For additional information write to:

District Chief

U.S. Geological Survey

Water Resources Division

821 East Interstate Avenue

Bismarck, ND 58501-1199
Copies of this report can be purchased from:

U.S. Geological Survey

Branch of Information Services

Box 25286

Denver, CO 80225-0286 


\section{CONTENTS}

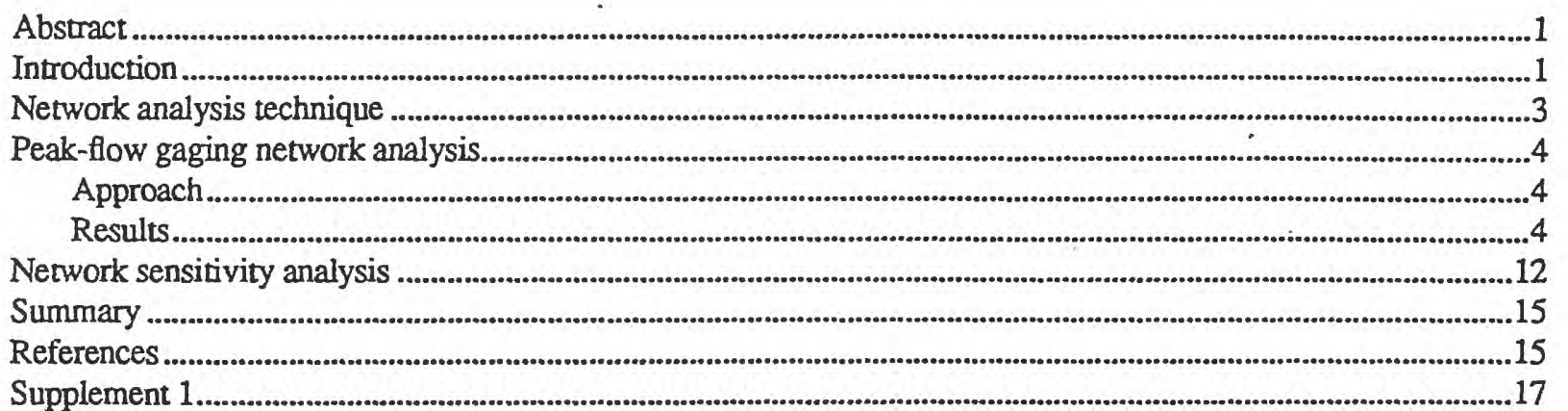

\section{FIGURES}

1. Graph showing distribution of current (1993) streamflow-gaging stations, by drainage area, in North Dakota.

2. Map showing location of gaging stations and hydrologic-region boundaries used in the generalized least-squares regression analysis update and the network analysis in North Dakota

3. Graphs showing results of network strategy in hydrologic regions $A, B$, and $C$ to provide regional information on 15-year peak flow in North Dakota.

4. Graphs showing results of network strategy in hydrologic regions $A, B$, and $C$ to provide regional information on 50-year peak flow in North Dakota

5. Graphs showing results of network strategy in hydrologic regions $A, B$, and $C$ to provide regional information on 100-year peak flow in North Dakota.

6. Graphs showing example of the network sensitivity analysis in hydrologic regions A, B, and C to provide regional information on 15 -year peak flow in North Dakota.

\section{TABLES}

1. Gaging station ranking in providing regional peak-flow information for hydrologic region $A$ and the percent reduction in the average sampling mean-square error.

2. Gaging station ranking in providing regional peak-flow information for hydrologic region $B$ and the percent reduction in the average sampling mean-square error .................................................................10

3. Gaging station ranking in providing regional peak-flow information for hydrologic region $\mathrm{C}$ and the percent reduction in the average sampling mean-square error.

4. Reduction in average sampling mean-square error with the addition of new gaging stations in hydrologic regions $\mathrm{A}, \mathrm{B}$, and $\mathrm{C}$ 


\title{
Analysis of the Peak-flow Gaging Network in North Dakota
}

\author{
By Tara Williams-Sether
}

\section{ABSTRACT}

A network analysis technique using generalized least-squares regression was used to evaluate the current (1993) peak-flow gaging network that provides regional peak-flow information for North Dakota. The analysis was conducted to evaluate the current (1993) network and to determine if reactivating discontinued gaging stations and adding new gaging stations on small drainage areas would improve regional peak-flow information.

Peak flows having recurrence intervals of 15,50 , and 100 years and planning horizons of zero and 10 years for three hydrologic regions in North Dakota were used in the network analysis. Results of the network analysis indicate that the average sampling mean-square error could be reduced by about 10 percent for the 15-, 50 -, and 100-year recurrence intervals by reactivating a minimum of two to five discontinued gaging stations in each hydrologic region. The reactivated discontinued gaging stations added to the current (1993) network should be located on streams having small drainage areas and steep main-channel slopes. For the 15-year recurrence interval and a 10-year planning horizon, adding a new gaging station at two new locations in each region instead of reactivating two discontinued gaging stations in each region would reduce the average - sampling mean-square error by an average of about 13 percent in each region. The new gaging stations added to the current (1993) network should be located on streams having small drainage areas and mild or steep main-channel slopes in order to obtain improved regional peak-flow information.

\section{INTRODUCTION}

Streamflow information are gathered at selected sites on streams across North Dakota on a continuous basis. Not all streams in the State are gaged, however. Peak-flow estimates for many of these ungaged streams are needed to provide essential flood information to planners and designers for various waterrelated projects. Peak-flow information collected at gaged streams are transferable to ungaged streams in a region through an empirical functional relation (usually a regression model) developed between streamflow characteristics and selected basin characteristics. This procedure is commonly referred to as "regionalization". Many of the streamflow-gaging stations in North Dakota were established primarily to provide information on current stream flow conditions at particular locations. However, information from some of these particular gaged locations may have limited transfer value, and are not suitable for regional analyses. Placement of streamflow-gaging stations to be used expressly for regionalization should provide spatial coverage of a region and should provide improved information for a range of basin and streamflow characteristics. Considered together, the group of stations and their characteristics make up a hypothetical data-collection "network" suitable for providing regional information. 
Any long-term data collection network should be evaluated periodically because of changes in objectives, technology, or external constraints. The last major evaluation of the streamflow-gaging network in North Dakota was performed by Crosby (1970). The uses, funding, and availability of streamflow data in North Dakota through 1984 were documented by Ryan (1985). The cost effectiveness of the streamflow-gaging network in eastern North Dakota was addressed by Ryan (1989). A network analysis that addresses the effect on the regional information that might be obtained from improved regional regression equations has not been attempted recently.

Regression equations for estimating peak flow for selected recurrence intervals for rural ungaged drainage areas throughout North Dakota were reported by Crosby (1975) and were updated by WilliamsSether (1992) using generalized least-squares (GLS) regression. The GLS technique not only provides an improved method for developing estimating equations based on data from an existing streamflow gaging network, but also may be used in evaluating the effectiveness of hypothetical changes to the gaging network in improving regional flood information. The current (1993) streamflow-gaging network in North Dakota consists of 107 continuous- and partial-record streamflow-gaging stations. Most of the gaging stations are located in drainage areas larger than 100 square miles (fig. 1). Williams-Sether (1992) reviewed the flood frequency data base and concluded that not enough current peak-flow records exist for small drainage areas. According to Williams-Sether (1992, p. 18), "Future peak-flow frequency studies for North Dakota streams could be improved if additional gaging stations were established or previously discontinued gaging stations were reestablished on natural-flow streams, especially for sites on streams with drainage areas of less than $200 \mathrm{mi}^{2}$." Thus, a need exists to evaluate the current streamflow network emphasizing watersheds having small drainage areas.

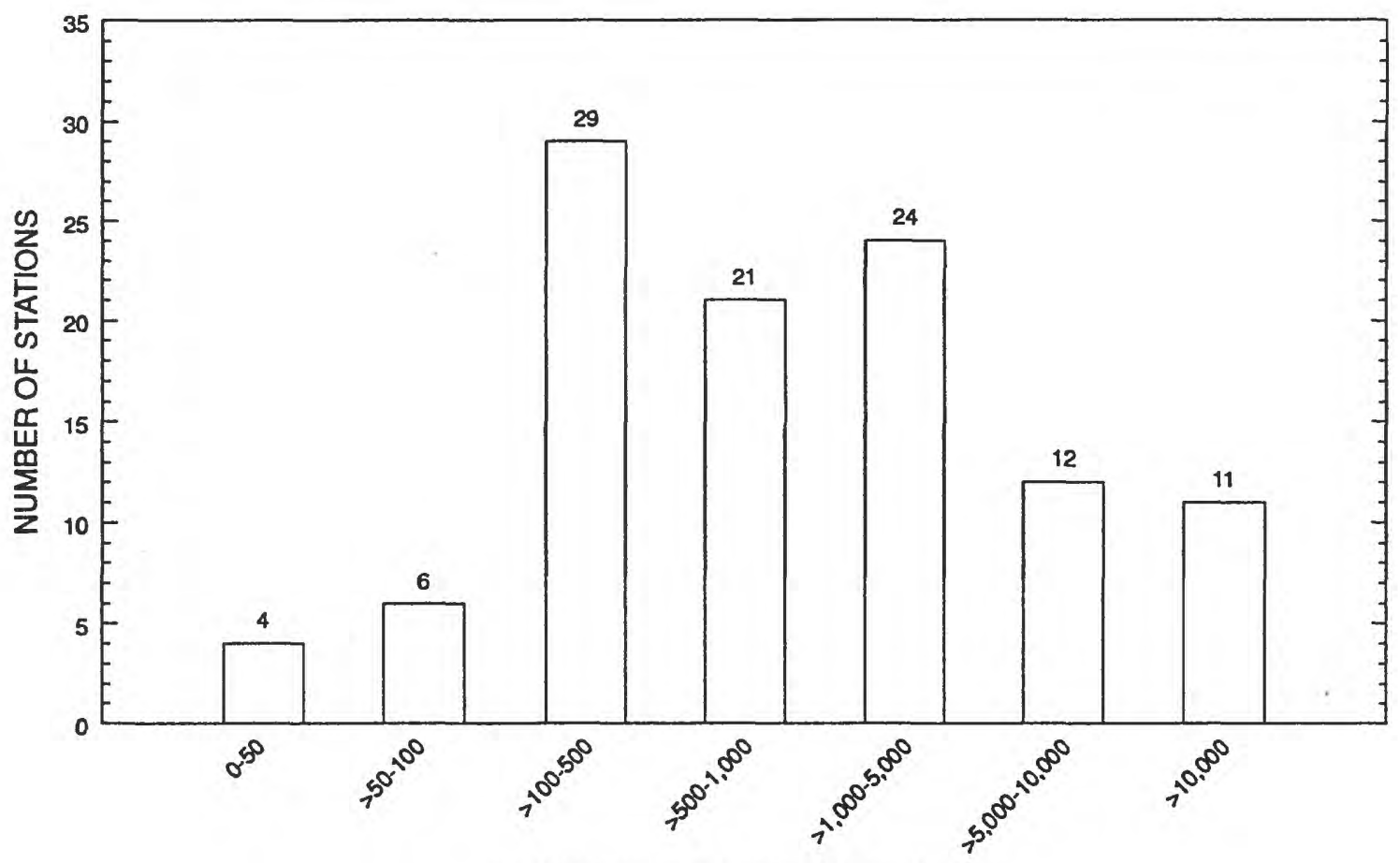

DRAINAGE AREA, IN SQUARE MILES

Figure 1. Distribution of current (1993) streamflow-gaging stations, by drainage area, in North Dakota. 
The purpose of this study was to evaluate the North Dakota streamflow-gaging network to determine what changes to the streamflow network would provide improved regional peak-flow information for small drainage areas. Improved information is obtained by relating peak-flow estimates to selected basin characteristics. Specific objectives were to (1) determine the effectiveness of the 1993 streamflow-gaging network in providing regional peak-flow information and (2) evaluate the potential improvements in the effectiveness of the 1993 network that would result from reactivating discontinued gaging stations and adding new gaging stations to the network. New gaging stations, unless otherwise noted, includes both continuous- and partial-record gaging stations. The study was limited to analysis of gaging stations in North Dakota and selected gaging stations in adjacent states. The streamflow-gaging network that was evaluated consisted of streamflow-gaging stations that were active in 1993 and gaging stations used by Williams-Sether (1992) updated through 1993. This report, which was prepared in cooperation with the North Dakota Department of Transportation, describes results of the study.

\section{NETWORK ANALYSIS TECHNIQUE}

The network analysis technique used in this study is based on the GLS regression (Tasker, 1986; Tasker, 1987). The GLS regression (Stedinger and Tasker, 1985) allows adjustments to be made for the cross correlation in concurrent record and for various lengths of record among gaging stations. A valuable feature of the GLS regression procedure for network analysis is that it provides a reliable estimate of the regression sampling error. The sampling error is the error in predicting the value of a particular flow statistic (in this case peak flow) due to estimating the true regression parameters. The sampling error is affected by the length of peak-flow record at a gaging station, the variability of the peak-flow values, the cross correlation with data from other gaging stations, and the combination of physical and climatic characteristics associated with the gaging station drainage area. The sampling error can be used to help evaluate the effect of either discontinuing existing gaging stations or adding new gaging stations to the network.

The network analysis can be used to address the question of whether to spend limited resources on collecting additional data at existing gaging stations, adding new gaging stations, or doing both. This determination is made by maximizing the regional regression model's predictive capability which is expressed as the inverse of the average variance of prediction of the model. The average variance of prediction is the variances of prediction averaged for a representative set of streamflow sites in a region. The variance of prediction at a site is made up of two independent parts: (1) the model error, which can be improved only by choosing a better model and (2) the sampling error, which can be improved by collecting additional data at existing or new gaging stations. It is assumed that the model will not change; therefore, the model error remains constant. The objective then is to minimize the sampling error. The average sampling mean-square error is a measure of the error in the average regression prediction in a region due to estimating with sample estimates of the regression coefficients. The average sampling mean-square error is a function of not only how long the gaging stations have been operated, but also where the gaging stations are in relation to each other and what values of basin and climatic characteristics are used in the regression. These properties make the average sampling mean-square error a good criterion by which to evaluate the trade off between extended records and additional gaging stations in a network analysis (Ruhl, 1993). Further explanations and examples of using the GLS regression procedure for network analyses may be found in reports by Medina (1987), Omang (1992), and Ruhl (1993). 


\section{PEAK-FLOW GAGING NETWORK ANALYSIS}

\section{Approach}

The network analyzed in this report consists of three sub-networks (fig. 2) corresponding to the three hydrologic regions specified by Williams-Sether (1992). In the network analysis, unregulated annual peak flow was the streamflow characteristic used for each gaging station for the period of record through water year 1993. All periods of record are in terms of water year. Water year in U.S. Geological Survey reports dealing with surface-water supply is the 12 -month period October 1 through September 30 . The water year is designated by the calendar year in which it ends and which includes 9 of the 12 months. Thus, the year ending September 30, 1993, is called the "1993 water year."

The basin characteristics used in the network analysis were those identified as significant in the GLS regression analyses by Williams-Sether (1992). The characteristics were contributing drainage area and main-channel slope. Because the flow of streams having large drainage areas generally is regulated and, therefore, is not applicable to the analysis, only gaging stations having drainage areas of 1,000 square miles or less were used in the network analysis.

Streamflow-gaging stations with 10 years or more of record were considered appropriate for use in the analysis. Exceptions were made for recently installed gaging stations in the current (1993) network that had 4 years or more of record. Three gaging stations in the current (1993) network had 3 years or less of record and were treated as new gaging stations in the network analysis. The gaging stations used in the analysis are listed in supplement 1 at the end of the report, and the locations are shown in figure 2.

The peak-flow regional regression equations for 15-, 50-, and 100-year recurrence intervals as defined by Williams-Sether (1992) were updated to include data through 1993 . Two hundred and one gaging stations were used to update the regression analyses, and the results were used for the network analysis (supplement 1). Only 175 gaging stations were used in the network analysis. The gaging stations that were not used in the analyses did not have the necessary basin characteristics or they were discontinued gaging stations located outside of North Dakota. Planning horizons of zero and 10 years were chosen for the network analysis. A zero-year planning horizon refers to conditions of the current (1993) network zero years into the future and assumes that no additional data would be collected at existing gaging stations and no reactivated or new gaging stations would be added to the network. A 10-year planning horizon - refers to conditions of the current (1993) network 10 years into the future and implies 10 years of additional data would be collected at existing gaging stations. A 10-year planning horizon may or may not include reactivated or new gaging stations added to the network during the 10 -year period. The network analysis for each of the 15-, 50-, and 100-year recurrence interval peak flows consisted of (1) the existing gaging stations and (2) the existing gaging stations plus discontinued gaging stations and recently installed ( 3 years or less of record) gaging stations.

\section{Results}

Results of the network analysis for hydrologic regions A, B, and C using the 15-, 50-, and 100-year recurrence interval peak flow are presented in figures 3,4 , and 5 and tables 1,2 , and 3 . The discontinued gaging stations and the recently installed gaging stations (one in region A and two in region B) are ranked in providing regional peak-flow information in tables 1,2 , and 3. The gaging stations are ranked according to a 10 -year planning horizon and 15-, 50-, and 100-year recurrence intervals. 


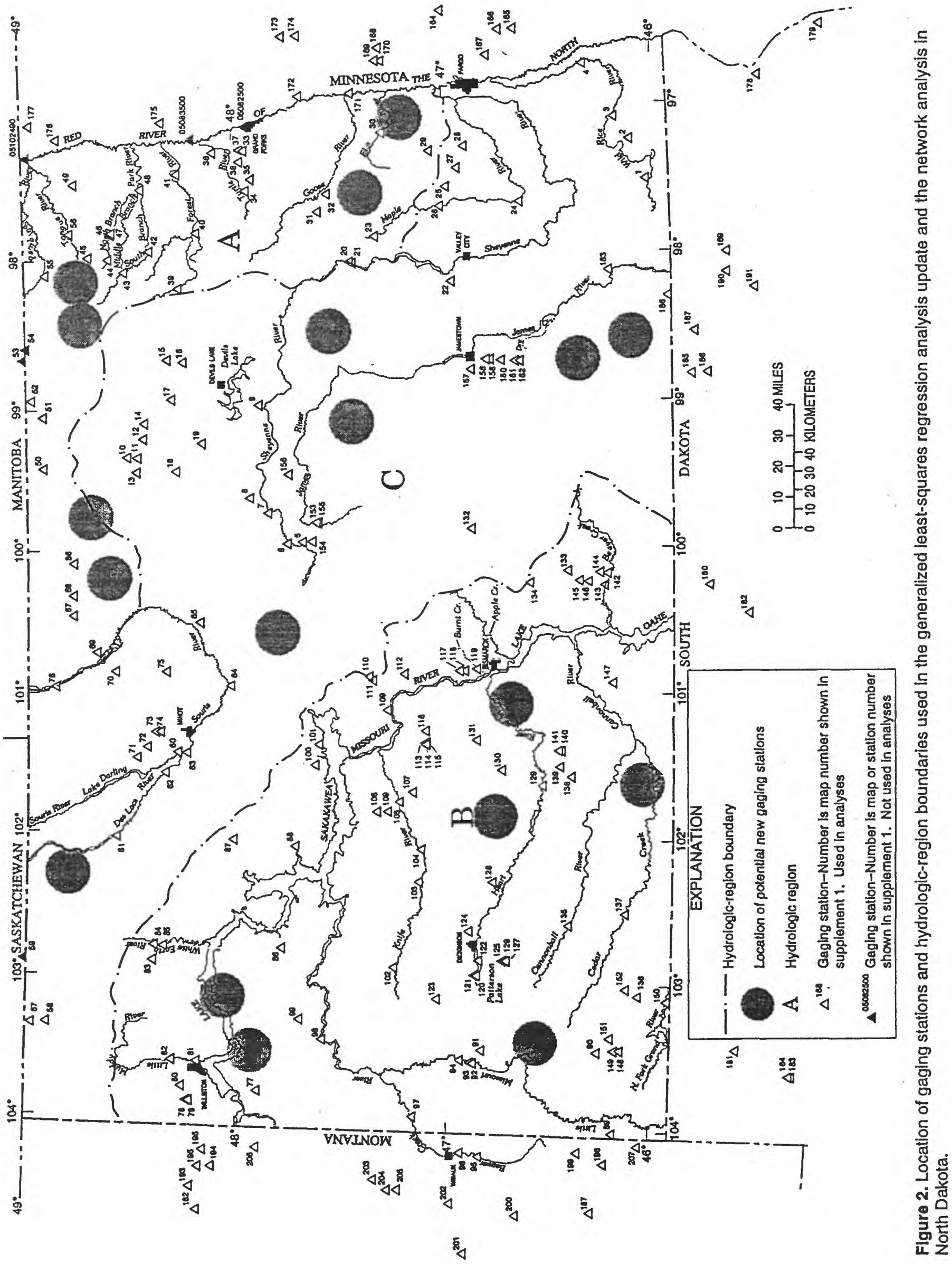



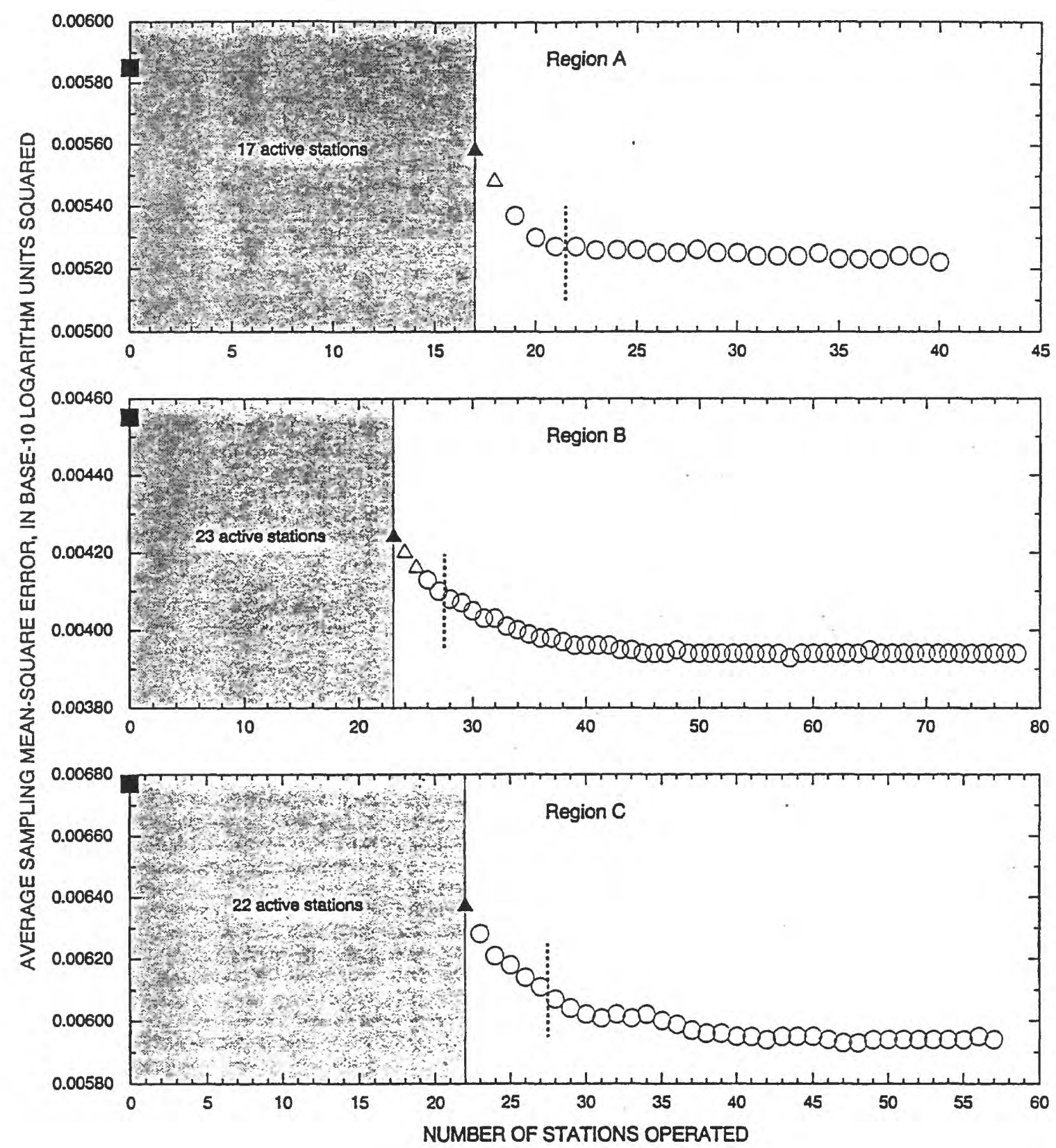

EXPLANATION

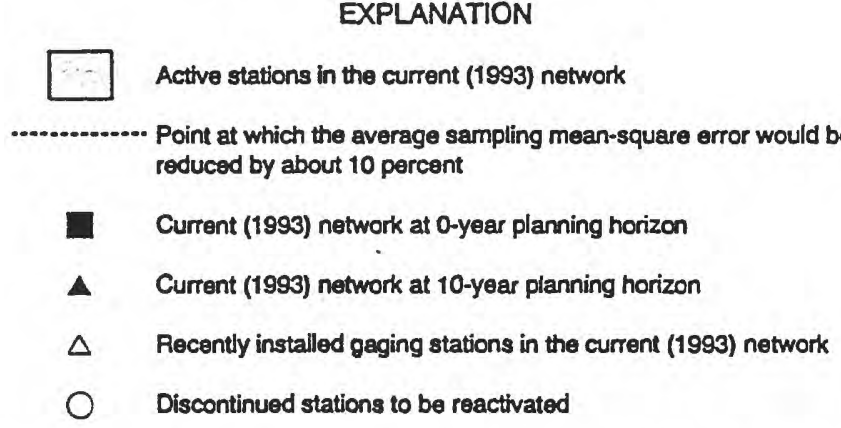

Figure 3. Results of network strategy in hydrologic regions $A, B$, and $C$ to provide regional information on 15-year peak flow in North Dakota. 

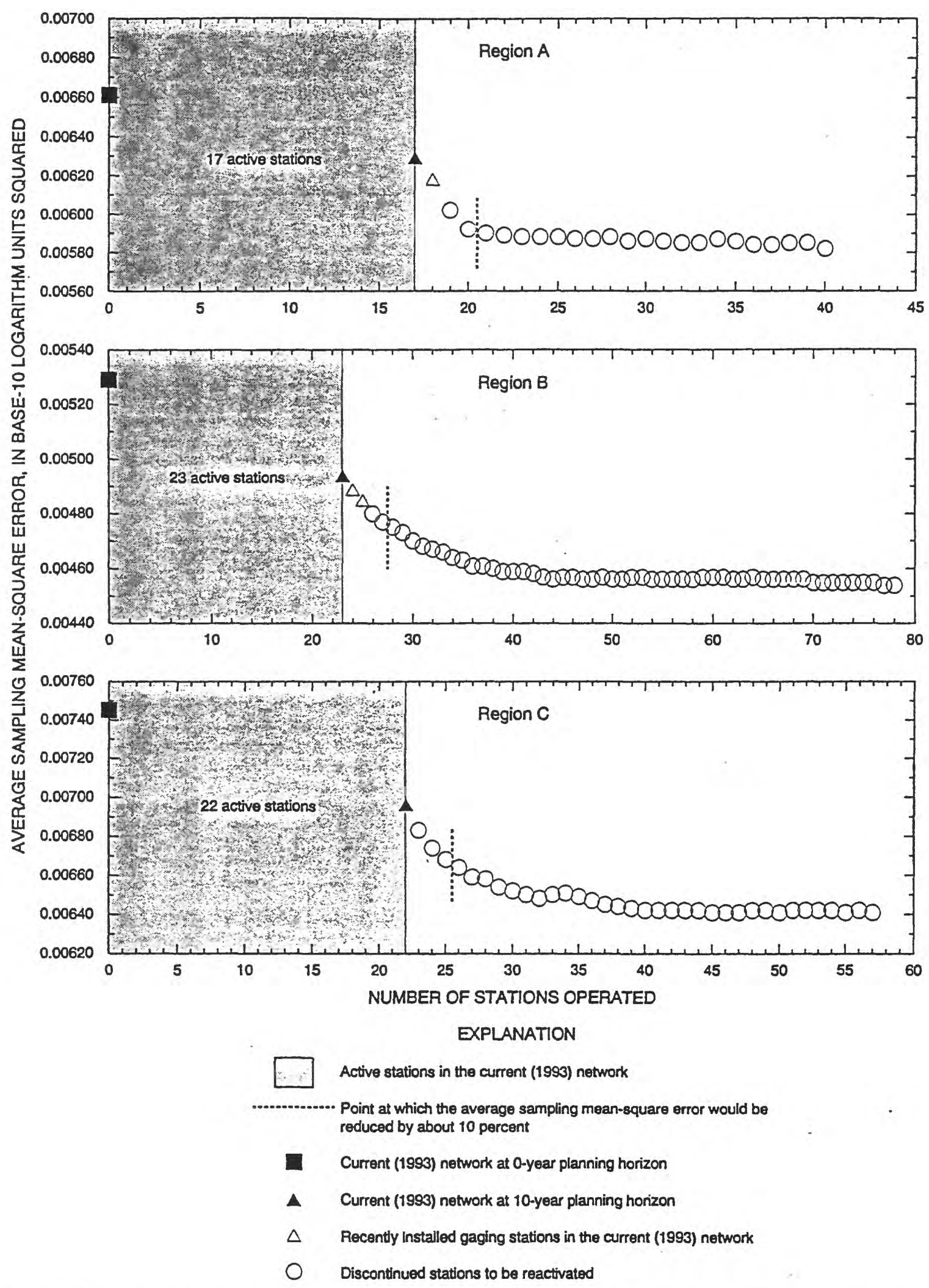

Figure 4. Results of network strategy in hydrologic regions $A, B$, and $C$ to provide regional information on 50 -year peak flow in North Dakota. 

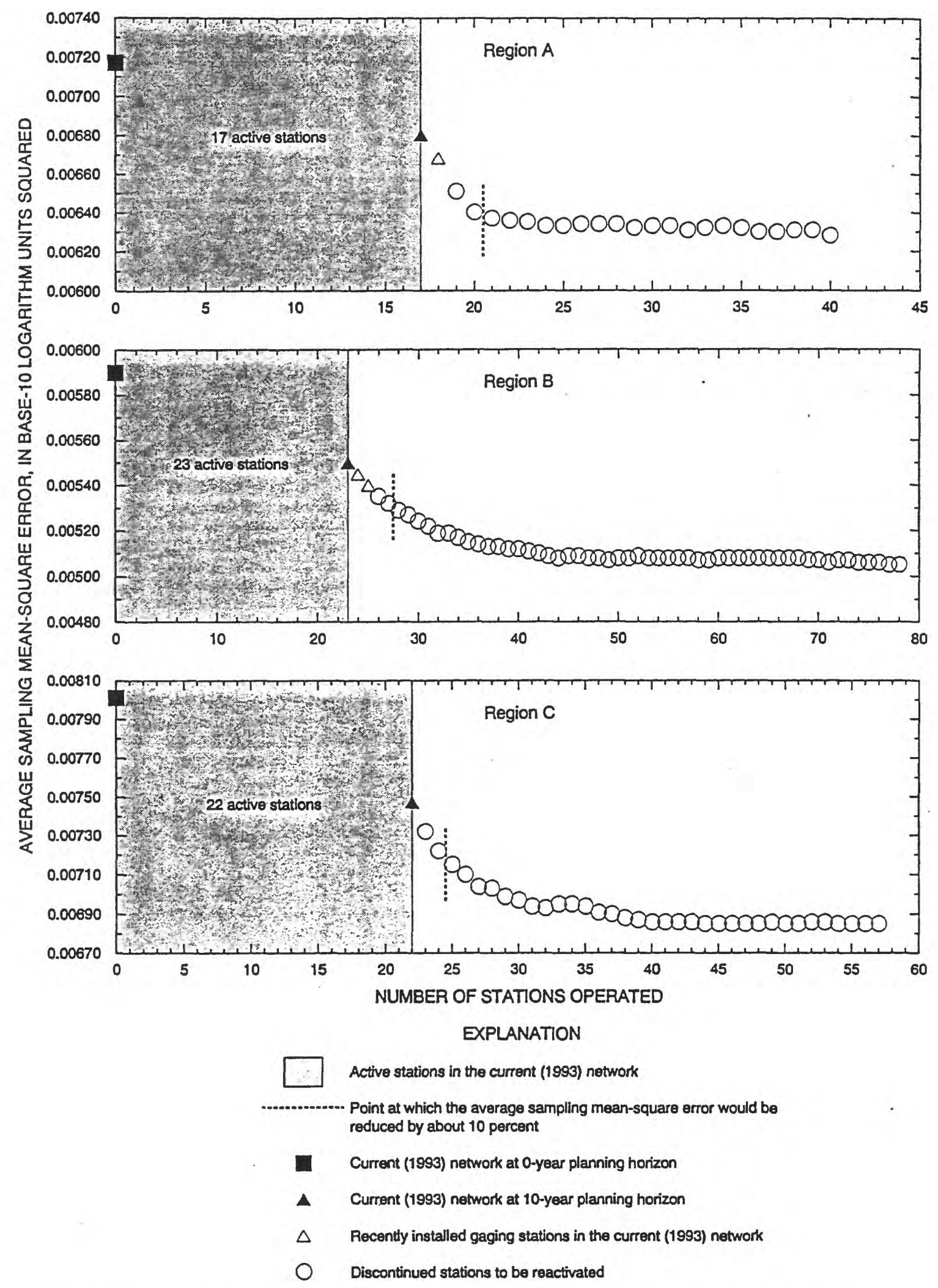

Figure 5. Results of network strategy in hydrologic regions $A, B$, and $C$ to provide regional information on 100-year peak flow in North Dakota. 
Table 1. Gaging station ranking in providing regional peak-flow information for hydrologic region $A$ and the percent reduction in the average sampling mean-square error

\begin{tabular}{|c|c|c|c|c|c|c|c|}
\hline $\begin{array}{l}\text { Station } \\
\text { number }\end{array}$ & $\begin{array}{l}\text { Ranking for } \\
15 \text {-year } \\
\text { recurrence } \\
\text { Interval }\end{array}$ & $\begin{array}{c}\text { Cumulative } \\
\text { error } \\
\text { reduction } \\
\text { (percent) }\end{array}$ & $\begin{array}{l}\text { Ranking for } \\
50 \text {-year } \\
\text { recurrence } \\
\text { Interval }\end{array}$ & $\begin{array}{c}\text { Cumulative } \\
\text { error } \\
\text { reduction } \\
\text { (percent) }\end{array}$ & $\begin{array}{l}\text { Ranking for } \\
\text { 100-year } \\
\text { recurrence } \\
\text { Interval }\end{array}$ & $\begin{array}{c}\text { Cumulative } \\
\text { error } \\
\text { reduction } \\
\text { (percent) }\end{array}$ & $\begin{array}{l}\text { Composite } \\
\text { ranking }\end{array}$ \\
\hline $\begin{array}{l}05056900 \\
05056950 \\
05062200 \\
05065500 \\
05082600\end{array}$ & $\begin{array}{r}6 \\
2 \\
15 \\
21 \\
18\end{array}$ & $\begin{array}{r}10.1 \\
8.2 \\
10.4 \\
10.4 \\
10.6\end{array}$ & $\begin{array}{r}6 \\
2 \\
14 \\
20 \\
19\end{array}$ & $\begin{array}{r}11.0 \\
8.9 \\
11.3 \\
11.6 \\
11.6\end{array}$ & $\begin{array}{r}6 \\
2 \\
14 \\
20 \\
19\end{array}$ & $\begin{array}{r}11.4 \\
9.2 \\
11.7 \\
12.1 \\
12.1\end{array}$ & $\begin{array}{r}6 \\
2 \\
14 \\
20 \\
19\end{array}$ \\
\hline $\begin{array}{r}105082625 \\
05082680 \\
05082700 \\
05082900 \\
05083600\end{array}$ & $\begin{array}{r}1 \\
9 \\
20 \\
14 \\
19\end{array}$ & $\begin{array}{r}6.3 \\
10.2 \\
10.6 \\
10.4 \\
10.6\end{array}$ & $\begin{array}{r}1 \\
9 \\
21 \\
15 \\
18\end{array}$ & $\begin{array}{r}6.6 \\
11.2 \\
11.5 \\
11.5 \\
11.3\end{array}$ & $\begin{array}{r}1 \\
7 \\
21 \\
15 \\
18\end{array}$ & $\begin{array}{r}7.0 \\
11.7 \\
12.0 \\
12.0 \\
11.8\end{array}$ & $\begin{array}{r}1 \\
9 \\
21 \\
15 \\
18\end{array}$ \\
\hline $\begin{array}{l}05088000 \\
05089100 \\
05089200 \\
05089500 \\
05089700\end{array}$ & $\begin{array}{r}7 \\
16 \\
10 \\
11 \\
13\end{array}$ & $\begin{array}{l}10.1 \\
10.4 \\
10.2 \\
10.1 \\
10.2\end{array}$ & $\begin{array}{r}7 \\
16 \\
10 \\
11 \\
13\end{array}$ & $\begin{array}{l}11.0 \\
11.5 \\
11.2 \\
11.0 \\
11.2\end{array}$ & $\begin{array}{r}9 \\
16 \\
11 \\
10 \\
13\end{array}$ & $\begin{array}{l}11.6 \\
11.8 \\
11.6 \\
11.6 \\
11.7\end{array}$ & $\begin{array}{r}7 \\
16 \\
10 \\
11 \\
13\end{array}$ \\
\hline $\begin{array}{l}05089800 \\
05092200 \\
05099400 \\
05098800 \\
05122500\end{array}$ & $\begin{array}{r}23 \\
22 \\
17 \\
12 \\
8\end{array}$ & $\begin{array}{l}10.8 \\
10.4 \\
10.2 \\
10.2 \\
10.1\end{array}$ & $\begin{array}{r}23 \\
22 \\
17 \\
12 \\
8\end{array}$ & $\begin{array}{l}12.0 \\
11.5 \\
11.2 \\
11.3 \\
11.0\end{array}$ & $\begin{array}{r}23 \\
22 \\
17 \\
12 \\
8\end{array}$ & $\begin{array}{l}12.4 \\
12.0 \\
11.7 \\
11.8 \\
11.7\end{array}$ & $\begin{array}{r}23 \\
22 \\
17 \\
12 \\
8\end{array}$ \\
\hline $\begin{array}{l}05123300 \\
05123350 \\
05123500\end{array}$ & $\begin{array}{l}4 \\
3 \\
5\end{array}$ & $\begin{array}{l}9.9 \\
9.4 \\
9.9\end{array}$ & $\begin{array}{r}4 \\
3 \\
5\end{array}$ & $\begin{array}{l}10.7 \\
10.4 \\
10.9\end{array}$ & $\begin{array}{l}4 \\
3 \\
5\end{array}$ & $\begin{array}{l}11.2 \\
10.7 \\
11.3\end{array}$ & $\begin{array}{l}4 \\
3 \\
5\end{array}$ \\
\hline
\end{tabular}

${ }^{1}$ Recently installed gaging station in the current (1993) network.

Series of symbols plotted on figures 3,4 , and 5 will be referred to as curves. The steep part of each curve represents the gaging stations that would be most effective in reducing the average sampling meansquare error. The flat part of each curve represents the gaging stations that would be least effective in reducing the average sampling mean-square error for the respective recurrence interval and would probably not be considered for inclusion into the network.

Results of the 15-year peak-flow recurrence interval analyses for hydrologic regions $\mathrm{A}, \mathrm{B}$, and $\mathrm{C}$ are shown in figure 3. The average sampling mean-square error for the current (1993) network from the zeroyear to the 10 -year planning horizon is reduced by 4.6 percent (from 0.00585 to 0.00558 ) in region $\mathrm{A}$, by 6.8 percent (from 0.00455 to 0.00424 ) in region $B$, and by 5.9 percent (from 0.00677 to 0.00637 ) in region $C$. Adding additional gaging stations to the network ( 23 in region A, 55 in region $B$, and 35 in region $C$ ) would reduce the average sampling mean-square error by 10.8 percent (from 0.00585 to 0.00522 ) in region $A$, by 13.4 percent (from 0.00455 to 0.00394 ) in region $B$, and by 12.3 percent (from 0.00677 to 0.00594 ) in region $C$. The additional gaging stations used in the analysis consisted of recently installed gaging stations in the current (1993) network and reactivated gaging stations that had been previously discontinued. The average sampling mean-square error would be reduced by about 10 percent (tables 1-3) by retaining recently installed gaging stations in the current (1993) network and by reactivating a minimum of three discontinued gaging stations in region $\mathrm{A}$, a minimum of two discontinued gaging stations in region $\mathrm{B}$, and a minimum of five discontinued gaging stations in region $\mathrm{C}$. 
Table 2. Gaging station ranking in providing regional peak-flow information for hydrologic region $B$ and the percent reduction in the average sampling mean-square error

\begin{tabular}{|c|c|c|c|c|c|c|c|}
\hline $\begin{array}{l}\text { Station } \\
\text { number }\end{array}$ & $\begin{array}{l}\text { Ranking for } \\
\text { 15-year } \\
\text { recurrence } \\
\text { interval }\end{array}$ & $\begin{array}{l}\text { Cumulative } \\
\text { error } \\
\text { reduction } \\
\text { (percent) }\end{array}$ & $\begin{array}{l}\text { Ranking for } \\
50 \text {-year } \\
\text { recurrence } \\
\text { Interval }\end{array}$ & $\begin{array}{l}\text { Cumulative } \\
\text { error } \\
\text { reduction } \\
\text { (percent) }\end{array}$ & $\begin{array}{l}\text { Ranking for } \\
\text { t00-year } \\
\text { recurrence } \\
\text { interval }\end{array}$ & $\begin{array}{l}\text { Cumulative } \\
\text { error } \\
\text { reductlon } \\
\text { (percent) }\end{array}$ & $\begin{array}{c}\text { Composite } \\
\text { ranking }\end{array}$ \\
\hline $\begin{array}{l}06329597 \\
06329700 \\
06329800 \\
06329900 \\
06330100\end{array}$ & $\begin{array}{l}26 \\
16 \\
52 \\
27 \\
33\end{array}$ & $\begin{array}{l}13.4 \\
13.0 \\
13.4 \\
13.4 \\
13.4\end{array}$ & $\begin{array}{l}25 \\
16 \\
52 \\
28 \\
32\end{array}$ & $\begin{array}{l}13.8 \\
13.2 \\
14.0 \\
13.8 \\
13.8\end{array}$ & $\begin{array}{l}25 \\
17 \\
52 \\
28 \\
32\end{array}$ & $\begin{array}{l}13.9 \\
13.2 \\
14.2 \\
13.9 \\
13.9\end{array}$ & $\begin{array}{l}25 \\
16 \\
52 \\
28 \\
32\end{array}$ \\
\hline $\begin{array}{r}06331900 \\
06332000 \\
06332150 \\
06332520 \\
{ }^{1} 06332770\end{array}$ & $\begin{array}{r}44 \\
48 \\
4 \\
.22 \\
1\end{array}$ & $\begin{array}{r}13.4 \\
13.4 \\
9.9 \\
13.4 \\
7.7\end{array}$ & $\begin{array}{r}46 \\
47 \\
4 \\
19 \\
1\end{array}$ & $\begin{array}{r}13.8 \\
14.0 \\
9.8 \\
13.4 \\
7.8\end{array}$ & $\begin{array}{r}46 \\
48 \\
4 \\
19 \\
1\end{array}$ & $\begin{array}{r}14.1 \\
14.2 \\
9.8 \\
13.6 \\
7.8\end{array}$ & $\begin{array}{r}46 \\
47 \\
4 \\
19 \\
1\end{array}$ \\
\hline $\begin{array}{l}06335000 \\
06335700 \\
06336100 \\
06336200 \\
06336300\end{array}$ & $\begin{array}{r}36 \\
8 \\
5 \\
28 \\
3\end{array}$ & $\begin{array}{r}13.4 \\
11.4 \\
10.3 \\
13.4 \\
9.2\end{array}$ & $\begin{array}{r}34 \\
8 \\
3 \\
39 \\
7\end{array}$ & $\begin{array}{r}13.8 \\
11.5 \\
9.3 \\
13.8 \\
11.2\end{array}$ & $\begin{array}{r}34 \\
8 \\
3 \\
39 \\
7\end{array}$ & $\begin{array}{r}13.9 \\
11.5 \\
9.3 \\
13.9 \\
11.2\end{array}$ & $\begin{array}{r}34 \\
8 \\
3 \\
39 \\
7\end{array}$ \\
\hline $\begin{array}{l}06336400 \\
06336980 \\
06337100 \\
06337600 \\
06337900\end{array}$ & $\begin{array}{r}32 \\
7 \\
29 \\
12 \\
6\end{array}$ & $\begin{array}{l}13.4 \\
11.0 \\
13.4 \\
12.3 \\
10.5\end{array}$ & $\begin{array}{r}31 \\
6 \\
27 \\
12 \\
5\end{array}$ & $\begin{array}{l}13.8 \\
10.6 \\
13.8 \\
12.5 \\
10.2\end{array}$ & $\begin{array}{r}31 \\
6 \\
26 \\
12 \\
5\end{array}$ & $\begin{array}{l}13.9 \\
10.7 \\
14.1 \\
12.7 \\
10.3\end{array}$ & $\begin{array}{r}31 \\
6 \\
27 \\
12 \\
5\end{array}$ \\
\hline $\begin{array}{l}06339300 \\
06339560 \\
06340528 \\
06340905 \\
06341400\end{array}$ & $\begin{array}{l}49 \\
25 \\
18 \\
13 \\
39\end{array}$ & $\begin{array}{l}13.4 \\
13.2 \\
13.0 \\
12.5 \\
13.4\end{array}$ & $\begin{array}{l}48 \\
26 \\
22 \\
15 \\
35\end{array}$ & $\begin{array}{l}14.0 \\
13.6 \\
13.6 \\
13.0 \\
13.8\end{array}$ & $\begin{array}{l}47 \\
27 \\
22 \\
16 \\
35\end{array}$ & $\begin{array}{l}14.1 \\
13.9 \\
13.7 \\
13.2 \\
14.1\end{array}$ & $\begin{array}{l}48 \\
26 \\
22 \\
15 \\
35\end{array}$ \\
\hline $\begin{array}{l}06342050 \\
06342100 \\
06342150 \\
06342250 \\
06342300\end{array}$ & $\begin{array}{l}55 \\
53 \\
17 \\
15 \\
24\end{array}$ & $\begin{array}{l}13.4 \\
13.4 \\
13.0 \\
12.7 \\
13.4\end{array}$ & $\begin{array}{l}55 \\
53 \\
17 \\
13 \\
23\end{array}$ & $\begin{array}{l}14.2 \\
14.0 \\
13.2 \\
12.8 \\
13.6\end{array}$ & $\begin{array}{l}55 \\
53 \\
15 \\
13 \\
23\end{array}$ & $\begin{array}{l}14.4 \\
14.2 \\
13.0 \\
12.9 \\
13.7\end{array}$ & $\begin{array}{l}55 \\
53 \\
17 \\
13 \\
23\end{array}$ \\
\hline $\begin{array}{l}06342350 \\
06343200 \\
06344200 \\
06345000 \\
06345100\end{array}$ & $\begin{array}{l}20 \\
10 \\
14 \\
38 \\
50\end{array}$ & $\begin{array}{l}13.2 \\
11.9 \\
12.5 \\
13.4 \\
13.4\end{array}$ & $\begin{array}{l}20 \\
11 \\
14 \\
37 \\
50\end{array}$ & $\begin{array}{l}13.6 \\
12.3 \\
12.8 \\
13.6 \\
14.0\end{array}$ & $\begin{array}{l}20 \\
11 \\
14 \\
36 \\
50\end{array}$ & $\begin{array}{l}13.7 \\
12.4 \\
13.0 \\
14.1 \\
14.1\end{array}$ & $\begin{array}{l}20 \\
11 \\
14 \\
37 \\
50\end{array}$ \\
\hline $\begin{array}{l}06345200 \\
06345300 \\
06345700 \\
06347000 \\
06348500\end{array}$ & $\begin{array}{l}35 \\
34 \\
46 \\
42 \\
47\end{array}$ & $\begin{array}{l}13.6 \\
13.4 \\
13.4 \\
13.2 \\
13.4\end{array}$ & $\begin{array}{l}38 \\
33 \\
45 \\
41 \\
49\end{array}$ & $\begin{array}{l}13.6 \\
13.8 \\
13.8 \\
13.6 \\
14.0\end{array}$ & $\begin{array}{l}38 \\
33 \\
44 \\
42 \\
49\end{array}$ & $\begin{array}{l}13.9 \\
13.9 \\
13.9 \\
13.9 \\
14.1\end{array}$ & $\begin{array}{l}38 \\
33 \\
45 \\
41 \\
49\end{array}$ \\
\hline $\begin{array}{r}06349200 \\
106354815 \\
06355310 \\
06353600 \\
06353700\end{array}$ & $\begin{array}{r}19 \\
2 \\
9 \\
11 \\
21\end{array}$ & $\begin{array}{r}13.0 \\
8.6 \\
11.4 \\
12.1 \\
13.2\end{array}$ & $\begin{array}{r}18 \\
2 \\
9 \\
10 \\
21\end{array}$ & $\begin{array}{r}13.2 \\
8.5 \\
11.7 \\
11.9 \\
13.8\end{array}$ & $\begin{array}{r}18 \\
2 \\
10 \\
9 \\
21\end{array}$ & $\begin{array}{r}13.4 \\
8.6 \\
12.0 \\
12.0 \\
13.9\end{array}$ & $\begin{array}{r}18 \\
2 \\
9 \\
10 \\
21\end{array}$ \\
\hline $\begin{array}{l}06353800 \\
06353900 \\
06354500 \\
06354700 \\
06354750\end{array}$ & $\begin{array}{l}45 \\
43 \\
37 \\
30 \\
23\end{array}$ & $\begin{array}{l}13.4 \\
13.4 \\
13.4 \\
13.4 \\
13.4\end{array}$ & $\begin{array}{l}44 \\
42 \\
36 \\
30 \\
24\end{array}$ & $\begin{array}{l}13.8 \\
13.8 \\
13.6 \\
13.6 \\
13.8\end{array}$ & $\begin{array}{l}45 \\
41 \\
37 \\
30 \\
24\end{array}$ & $\begin{array}{l}13.9 \\
13.9 \\
13.9 \\
13.9 \\
13.9\end{array}$ & $\begin{array}{l}44 \\
42 \\
36 \\
30 \\
24\end{array}$ \\
\hline $\begin{array}{l}06354800 \\
06354900 \\
06354950 \\
06355000 \\
06355200\end{array}$ & $\begin{array}{l}41 \\
54 \\
40 \\
31 \\
51\end{array}$ & $\begin{array}{l}13.4 \\
13.4 \\
13.4 \\
13.4 \\
13.4\end{array}$ & $\begin{array}{l}43 \\
54 \\
40 \\
29 \\
51\end{array}$ & $\begin{array}{l}13.8 \\
14.2 \\
13.8 \\
13.6 \\
14.0\end{array}$ & $\begin{array}{l}43 \\
54 \\
40 \\
29 \\
51\end{array}$ & $\begin{array}{l}13.9 \\
14.4 \\
13.9 \\
13.7 \\
14.2\end{array}$ & $\begin{array}{l}43 \\
54 \\
40 \\
29 \\
51\end{array}$ \\
\hline
\end{tabular}

${ }^{1}$ Recently installed gaging station in the current (1993) network. 
Table 3. Gaging station ranking in providing regional peak-flow information for hydrologic region $C$ and the percent reduction in the average sampling mean-square error

\begin{tabular}{|c|c|c|c|c|c|c|c|}
\hline $\begin{array}{l}\text { Station } \\
\text { number }\end{array}$ & $\begin{array}{l}\text { Ranking for } \\
\text { 15-year } \\
\text { recurrence } \\
\text { interval }\end{array}$ & $\begin{array}{l}\text { Cumulative } \\
\text { error } \\
\text { reduction } \\
\text { (percent) }\end{array}$ & $\begin{array}{l}\text { Ranking for } \\
50 \text {-year } \\
\text { recurrence } \\
\text { interval }\end{array}$ & $\begin{array}{c}\text { Cumulative } \\
\text { error } \\
\text { reduction } \\
\text { (percent) }\end{array}$ & $\begin{array}{l}\text { Ranking for } \\
100 \text {-year } \\
\text { recurrence } \\
\text { interval }\end{array}$ & $\begin{array}{l}\text { Cumulative } \\
\text { error } \\
\text { reduction } \\
\text { (percent) }\end{array}$ & $\begin{array}{l}\text { Composite } \\
\text { ranklng }\end{array}$ \\
\hline $\begin{array}{l}05051800 \\
05051900 \\
05052500 \\
05055000 \\
05055100\end{array}$ & $\begin{array}{r}4 \\
24 \\
30 \\
10 \\
34\end{array}$ & $\begin{array}{r}9.3 \\
12.3 \\
12.3 \\
11.1 \\
12.1\end{array}$ & $\begin{array}{r}3 \\
28 \\
26 \\
11 \\
34\end{array}$ & $\begin{array}{l}10.3 \\
14.0 \\
13.8 \\
12.8 \\
13.8\end{array}$ & $\begin{array}{r}3 \\
28 \\
26 \\
11 \\
34\end{array}$ & $\begin{array}{l}10.7 \\
14.5 \\
14.5 \\
13.2 \\
14.5\end{array}$ & $\begin{array}{r}3 \\
28 \\
26 \\
11 \\
34\end{array}$ \\
\hline $\begin{array}{l}05055200 \\
05055520 \\
05056020 \\
05056040 \\
05056080\end{array}$ & $\begin{array}{r}22 \\
8 \\
27 \\
19 \\
31\end{array}$ & $\begin{array}{l}12.1 \\
11.1 \\
12.3 \\
12.1 \\
12.3\end{array}$ & $\begin{array}{r}21 \\
8 \\
29 \\
19 \\
31\end{array}$ & $\begin{array}{l}13.8 \\
12.5 \\
13.8 \\
13.8 \\
13.8\end{array}$ & $\begin{array}{r}20 \\
8 \\
29 \\
19 \\
31\end{array}$ & $\begin{array}{l}14.4 \\
13.0 \\
14.5 \\
14.4 \\
14.4\end{array}$ & $\begin{array}{r}21 \\
8 \\
29 \\
19 \\
31\end{array}$ \\
\hline $\begin{array}{l}05056300 \\
05059800 \\
05059850 \\
05059900 \\
05059950\end{array}$ & $\begin{array}{l}23 \\
33 \\
14 \\
28 \\
18\end{array}$ & $\begin{array}{l}12.1 \\
12.3 \\
11.5 \\
12.3 \\
12.1\end{array}$ & $\begin{array}{l}25 \\
32 \\
13 \\
30 \\
18\end{array}$ & $\begin{array}{l}14.0 \\
13.8 \\
12.9 \\
13.8 \\
13.8\end{array}$ & $\begin{array}{l}25 \\
32 \\
13 \\
30 \\
18\end{array}$ & $\begin{array}{l}14.5 \\
14.5 \\
13.4 \\
14.4 \\
14.4\end{array}$ & $\begin{array}{l}25 \\
32 \\
13 \\
30 \\
18\end{array}$ \\
\hline $\begin{array}{l}05113450 \\
05113520 \\
05116100 \\
05116200 \\
05116550\end{array}$ & $\begin{array}{r}9 \\
2 \\
1 \\
5 \\
12\end{array}$ & $\begin{array}{r}11.2 \\
8.3 \\
7.2 \\
9.7 \\
11.1\end{array}$ & $\begin{array}{r}9 \\
2 \\
1 \\
4 \\
12\end{array}$ & $\begin{array}{r}12.8 \\
9.5 \\
8.3 \\
10.9 \\
12.6\end{array}$ & $\begin{array}{r}10 \\
2 \\
1 \\
4 \\
12\end{array}$ & $\begin{array}{r}13.5 \\
9.9 \\
8.6 \\
11.4 \\
13.2\end{array}$ & $\begin{array}{r}9 \\
2 \\
1 \\
4 \\
12\end{array}$ \\
\hline $\begin{array}{l}05117200 \\
05123520 \\
05123540 \\
05123560 \\
05123580\end{array}$ & $\begin{array}{r}3 \\
15 \\
32 \\
7 \\
35\end{array}$ & \begin{tabular}{r|}
8.7 \\
11.8 \\
12.3 \\
10.8 \\
12.3
\end{tabular} & $\begin{array}{r}6 \\
14 \\
33 \\
7 \\
35\end{array}$ & $\begin{array}{l}11.7 \\
13.2 \\
14.0 \\
12.2 \\
14.0\end{array}$ & $\begin{array}{r}6 \\
14 \\
33 \\
7 \\
35\end{array}$ & $\begin{array}{l}12.2 \\
13.7 \\
14.5 \\
12.7 \\
14.5\end{array}$ & $\begin{array}{r}6 \\
14 \\
33 \\
7 \\
35\end{array}$ \\
\hline $\begin{array}{l}05123600 \\
06349100 \\
06467650 \\
06467800 \\
06467900\end{array}$ & $\begin{array}{l}26 \\
13 \\
20 \\
21 \\
11\end{array}$ & $\begin{array}{l}12.4 \\
11.4 \\
12.3 \\
12.1 \\
11.2\end{array}$ & $\begin{array}{l}24 \\
15 \\
20 \\
22 \\
10\end{array}$ & $\begin{array}{l}14.0 \\
13.4 \\
13.8 \\
13.8 \\
13.0\end{array}$ & $\begin{array}{r}22 \\
15 \\
21 \\
24 \\
9\end{array}$ & $\begin{array}{l}14.5 \\
13.8 \\
14.4 \\
14.5 \\
13.4\end{array}$ & $\begin{array}{l}24 \\
15 \\
20 \\
22 \\
10\end{array}$ \\
\hline $\begin{array}{l}06469500 \\
06469600 \\
06470200 \\
06470300 \\
06470400\end{array}$ & $\begin{array}{r}29 \\
16 \\
6 \\
25 \\
17\end{array}$ & $\begin{array}{l}12.3 \\
12.0 \\
10.3 \\
12.4 \\
12.0\end{array}$ & $\begin{array}{r}27 \\
16 \\
5 \\
23 \\
17\end{array}$ & $\begin{array}{l}13.8 \\
13.6 \\
11.5 \\
14.0 \\
13.7\end{array}$ & $\begin{array}{r}27 \\
16 \\
5 \\
23 \\
17\end{array}$ & $\begin{array}{l}14.4 \\
14.1 \\
12.1 \\
14.5 \\
14.2\end{array}$ & $\begin{array}{r}27 \\
16 \\
5 \\
23 \\
17\end{array}$ \\
\hline
\end{tabular}

Results of the 50-year peak-flow recurrence interval analyses for hydrologic regions $\mathrm{A}, \mathrm{B}$, and $\mathrm{C}$ are shown in figure 4. The average sampling mean-square error for the current (1993) network from the zeroyear to the 10 -year planning horizon is reduced by 5.0 percent (from 0.00661 to 0.00628 ) in region $\mathrm{A}$, by 6.8 percent (from 0.00529 to 0.00493 ) in region $B$, and by 6.7 percent (from 0.00745 to 0.00695 ) in region $C$. Adding additional gaging stations to the network ( 23 in region $A, 55$ in region $B$, and 35 in region $C$ ) would reduce the average sampling mean-square error by 12.0 percent (from 0.00661 to 0.00582 ) in region $A$, by 14.2 percent (from 0.00529 to 0.00454 ) in region $B$, and by 14.0 percent (from 0.00745 to 0.00641 ) in region $C$. The additional gaging stations used in the analysis consisted of recently installed gaging stations in the current (1993) network and reactivated gaging stations that had been previously discontinued. The average sampling mean-square error would be reduced by about 10 percent (tables 1-3) by retaining recently installed gaging stations in the current (1993) network and by reactivating a minimum of two discontinued stations in regions $\mathrm{A}$ and $\mathrm{B}$ and a minimum of three discontinued gaging stations in region $\mathrm{C}$. 
Results of the 100-year peak-flow recurrence interval analyses for hydrologic regions $\mathrm{A}, \mathrm{B}$, and $\mathrm{C}$ are shown in figure 5. The average sampling mean-square error for the current (1993) network from the zeroyear to the 10 -year planning horizon is reduced by 5.3 percent (from 0.00717 to 0.00679 ) in region $\mathrm{A}$, by 6.9 percent (from 0.00590 to 0.00549 ) in region $B$, and by 6.9 percent (from 0.00801 to 0.00746 ) in region $\mathrm{C}$. Adding additional gaging stations to the network ( 23 in region $\mathrm{A}, 55$ in region $\mathrm{B}$, and 35 in region $C$ ) would reduce the average sampling mean-square error by 12.4 percent (from 0.00717 to 0.00628 ) in region $A$, by 14.4 percent (from 0.00590 to 0.00505 ) in region $B$, and by 14.5 percent (from 0.00801 to 0.00685 ) in region $C$. The additional gaging stations used in the analysis consisted of recently installed gaging stations in the current (1993) network and reactivated discontinued gaging stations. The average sampling mean-square error would be reduced by about 10 percent (tables $1-3$ ) by retaining recently installed gaging stations in the current (1993) network and by reactivating two discontinued gaging stations in region $\mathrm{A}$ and a minimum of two discontinued gaging stations in regions $\mathrm{B}$ and $\mathrm{C}$.

The results of the network analysis indicate that in order to obtain improved regional peak-flow information and reduce the average sampling mean-square error, emphasis should be on reactivating discontinued gaging stations at stream locations having small drainage areas and steep main-channel slopes. The average contributing drainage area and average main-channel slope of the current (1993) network with no additional gaging stations added to the network are 332 square miles and 7.8 feet per mile in region A, 264 square miles and 12.9 feet per mile in region B, and 263 square miles and 6.6 feet per mile in region $\mathrm{C}$. The average contributing drainage area and average main-channel slope of the reactivated discontinued gaging stations in each region that provide about 10 percent reduction in the average sampling mean-square error of the current (1993) network for the 15-, 50-, and 100-year recurrence intervals are 1.2 square miles and 164 feet per mile in region A, 0.31 square miles and 120 feet per mile in region B, and 1.24 square miles and 103 feet per mile in region $C$.

\section{NETWORK SENSITIVITY ANALYSIS}

A network sensitivity analysis was performed to evaluate drainage area, main-channel slope, and location of gaging stations in reducing the average sampling mean-square error of the current (1993) network. Also determined in the analysis was whether a greater reduction in the average sampling meansquare error would occur by reactivating discontinued gaging stations or by adding new gaging stations to the network. Several analyses were made for each hydrologic region (A, B, and C) using peak flow for the 15 -year recurrence interval and a 10-year planning horizon. Combinations of three drainage areas $(0.5$, 5.0 , and 25.0 square miles) and three values of main-channel slopes (3.0,30.0, and 300 feet per mile) were tested at various locations (fig. 2) in each region for a total of nine different site conditions at each new gaging-station location. Small drainage areas were chosen because of the general lack of small drainage areas in the current (1993) network, because the results of the network analysis for the 15-, 50-, and 100-year peak-flow recurrence intervals indicated their importance, and because most large drainage areas $(>1,000)$ have regulation of some kind. Mild (3.0 feet per mile) and moderate ( 30.0 feet per mile) mainchannel slopes were chosen because of the good possibility of finding such a slope at a given location. Steep (300 feet per mile) main-channel slopes, although uncommon, were chosen because the results of the network analysis for the 15-, 50-, and 100-year peak-flow recurrence intervals indicated their importance.

The results of the sensitivity analyses indicated that location was a factor in new gaging-station site selection. Selecting a location that is distant from existing gaging stations would provide greater reduction in error than selecting a location in an area with existing gaging stations. Small drainage areas and mild and steep main-channel slopes were indicated to be the preferable site conditions to be considered for potential new gaging-station sites (table 4). Depending on site conditions, adding a new gaging station at 
the best two of the six locations (fig. 1) in each region instead of reactivating two discontinued gaging stations in each region would reduce the average sampling mean-square error from about 9 percent in region $\mathrm{A}$ (table 1 ), about 10 percent in region $\mathrm{B}$ (table 2 ), and about 8 percent in region $\mathrm{C}$ (table 3 ) to an average of about 13 percent in each region. By adding a new gaging station at all six locations in each region, the average reduction in the average sampling mean-square error for all of the regions combined is about 19 percent. For a drainage area of 0.5 square mile and a main-channel slope of 3.0 feet per mile, adding two new locations for gaging stations in region $\mathrm{A}$, one in region $\mathrm{B}$, and two in region $\mathrm{C}$ instead of reactivating two discontinued gaging stations in each region would reduce the average sampling meansquare error by about 15 percent (fig. 6). If new locations with small drainage areas and mild or steep main-channel slopes are considered in future gaging-station site selections, a greater reduction in the average sampling mean-square error would occur than by reactivating discontinued gaging stations.

Table 4. Reduction in average sampling mean-square error with the addition of new gaging stations in hydrologic regions $\mathrm{A}, \mathrm{B}$, and $\mathrm{C}$ (for example, by adding a new gaging station that has a drainage area of 0.5 square mile and a main-channel slope of 3 feet per mile at the best two locations in region $A$, the error would be reduced by 15.2 percent)

\begin{tabular}{|c|c|c|c|c|}
\hline \multirow[b]{2}{*}{$\begin{array}{l}\text { Drainage area } \\
\text { (square miles) }\end{array}$} & \multirow[b]{2}{*}{$\begin{array}{l}\text { Main-channet slope } \\
\text { (feet per mile) }\end{array}$} & \multicolumn{3}{|c|}{$\begin{array}{l}\text { Reduction in average sampling mean-square error }{ }^{1} \\
\text { (percent) }\end{array}$} \\
\hline & & Region A & Region B & Region C \\
\hline \multicolumn{5}{|c|}{ Best two locations } \\
\hline 0.5 & 3 & 15.2 & 17.4 & 15.1 \\
\hline 5 & 30 & 13.7 & 12.8 & 12.0 \\
\hline 5 & 300 & 16.4 & 13.8 & 14.6 \\
\hline 5 & 3 & 11.8 & 14.5 & 11.4 \\
\hline 5 & 30 & 10.8 & 10.8 & 9.6 \\
\hline 5 & 300 & 15.0 & 14.7 & 14.3 \\
\hline 25 & 3 & 9.9 & 12.3 & 9.3 \\
\hline 25 & 30 & 9.7 & 10.6 & 9.3 \\
\hline 25 & 300 & 14.7 & 15.6 & 14.8 \\
\hline \multicolumn{5}{|c|}{ All six locations } \\
\hline 0.5 & 3 & 21.4 & 22.2 & 21.4 \\
\hline .5 & 30 & 20.7 & 17.8 & 18.6 \\
\hline 5 & 300 & 23.9 & 19.8 & 21.4 \\
\hline 5 & 3 & 17.4 & 19.3 & 17.3 \\
\hline 5 & 30 & 16.6 & 14.3 & 14.8 \\
\hline 5 & 300 & 22.0 & 20.2 & 20.5 \\
\hline 25 & 3 & ${ }^{2} 16.2$ & 16.7 & ${ }^{2} 15.2$ \\
\hline 25 & 30 & 14.5 & 13.8 & 13.7 \\
\hline 25 & 300 & 21.2 & 20.7 & 20.5 \\
\hline
\end{tabular}

\footnotetext{
${ }^{1}$ Applies to current (1993) network at 10-year planning horizon and 15-year peak flow. One percent reduction in error is the error percentage of the current (1993) network that would be reduced if indicated number of new gaging stations were added.

${ }^{2}$ One discontinued gaging station included prior to inclusion of final six new gaging stations.
} 

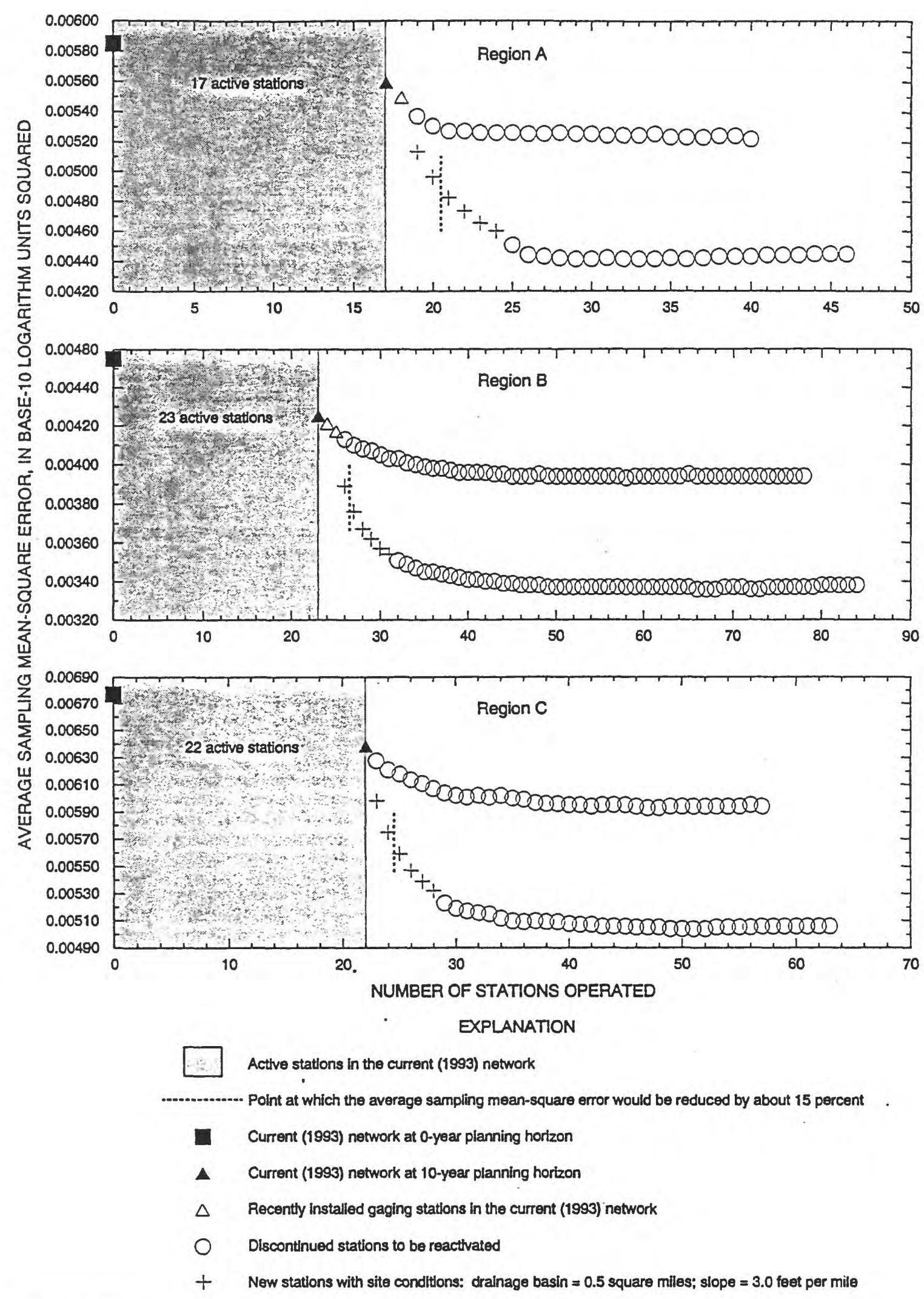

Flgure 6. Example of the network sensitivity analysis in hydrologic regions $A, B$, and $C$ to provide regional information on 15-year peak flow in North Dakota. 


\section{SUMMARY}

A network analysis technique using generalized least-squares regression was used to evaluate the current (1993) peak-flow gaging network in North Dakota. The analysis was conducted to determine the effectiveness of the 1993 network in providing regional peak-flow information and to evaluate the potential improvements in the effectiveness of the 1993 network by reactivating discontinued gaging stations and adding new gaging stations on small drainage areas to provide improved regional peak-flow information. A network analysis that addresses the effect on the regional information that might be obtained from improved regression equations has not been attempted since the 1970's.

The network analysis was performed for three hydrologic regions using peak flows having recurrence intervals of 15,50 , and 100 years. Zero-year and 10-year planning horizons were considered. Results of the network analysis determined which discontinued gaging stations, if reactivated, would contribute most to reducing the average sampling mean-square error for the indicated recurrence intervals and planning horizons. If the current (1993) network with no additional gaging stations is continued for 10 additional years, the reduction in the average sampling mean-square error would range from 4.6 to 6.9 percent among the three hydrologic regions. The average sampling mean-square error of the current (1993) network would be reduced by about 10 percent for the 15-,50-, and 100-year recurrence intervals by reactivating a minimum of two to three discontinued gaging stations in region A, two discontinued gaging stations in region $B$, and two to five discontinued gaging stations in region $C$. Results of the network analysis indicate that to obtain improved regional peak-flow information, emphasis should be on reactivating discontinued gaging stations in the current (1993) network that are located on streams having small drainage areas and steep main-channel slopes.

A network sensitivity analysis was performed to evaluate drainage area, main-channel slope, and location of gaging stations in reducing the average sampling mean-square error of the current (1993) network. For the 15-year recurrence interval and a 10-year planning horizon, adding a new gaging station at two new locations in each region instead of reactivating two discontinued gaging stations in each region would reduce the average sampling mean-square error by an average of about 13 percent in each region. Results of the sensitivity analysis indicate that adding new gaging stations with small drainage areas and mild or steep main-channel slopes would provide improved peak-flow information.

\section{REFERENCES}

Crosby, O.A., 1970, A proposed streamflow data program for North Dakota: U.S. Geological Survey Open-File Report, 68 p.

1975, Magnitude and frequency of floods in small drainage basins in North Dakota: U.S. Geological Survey Water-Resources Investigations Report 19-75, 24 p.

Medina, K.D., 1987, Analysis of surface-water data network in Kansas for effectiveness in providing regional streamflow information: U.S. Geological Survey Water-Supply Paper 2303, 28 p.

Omang, R.J., 1992, Analysis of the magnitude and frequency of floods and the peak-flow gaging network in Montana: U.S. Geological Survey Water-Resources Investigations Report 92-4048, 70 p.

Ruhl, K.J., 1993, Effectiveness of the streamflow-gaging network in Kentucky in providing regional streamflow information: U.S. Geological Survey Water-Resources Investigations Report 93-4106, 28 p. 
Ryan, G.L., 1985, Data uses and funding of the streamflow-gaging program in North Dakota: U.S. Geological Survey Open-File Report 85-349, 29 p.

1989, Cost effectiveness of the stream-gaging program in North Dakota: U.S. Geological Survey WaterResources Investigations Report 89-4068, 34 p.

Stedinger, J.R., and Tasker, G.D., 1985, Regional hydrologic analysis, 1. Ordinary, weighted, and generalized least squares compared: Water Resources Research, v. 21, no. 9, p. 1421-1432.

Tasker, G.D. 1986, Generating efficient gaging plans for regional information, in Moss, M.E., ed., Integrated design of hydrologic networks: International Association of Hydrological Sciences, no. 158, p. 269-281.

1987, Theory and application of GLS, in Medina, K.D., Analysis of surface-water data network in Kansas for effectiveness in providing regional streamflow information: U.S. Geological Survey Water-Supply Paper 2303, p. 24-26.

Williams-Sether, Tara, 1992, Techniques for estimating peak-flow frequency relations for North Dakota streams: U.S. Geological Survey Water-Resources Investigations Report 92-4020, $57 \mathrm{p}$. 


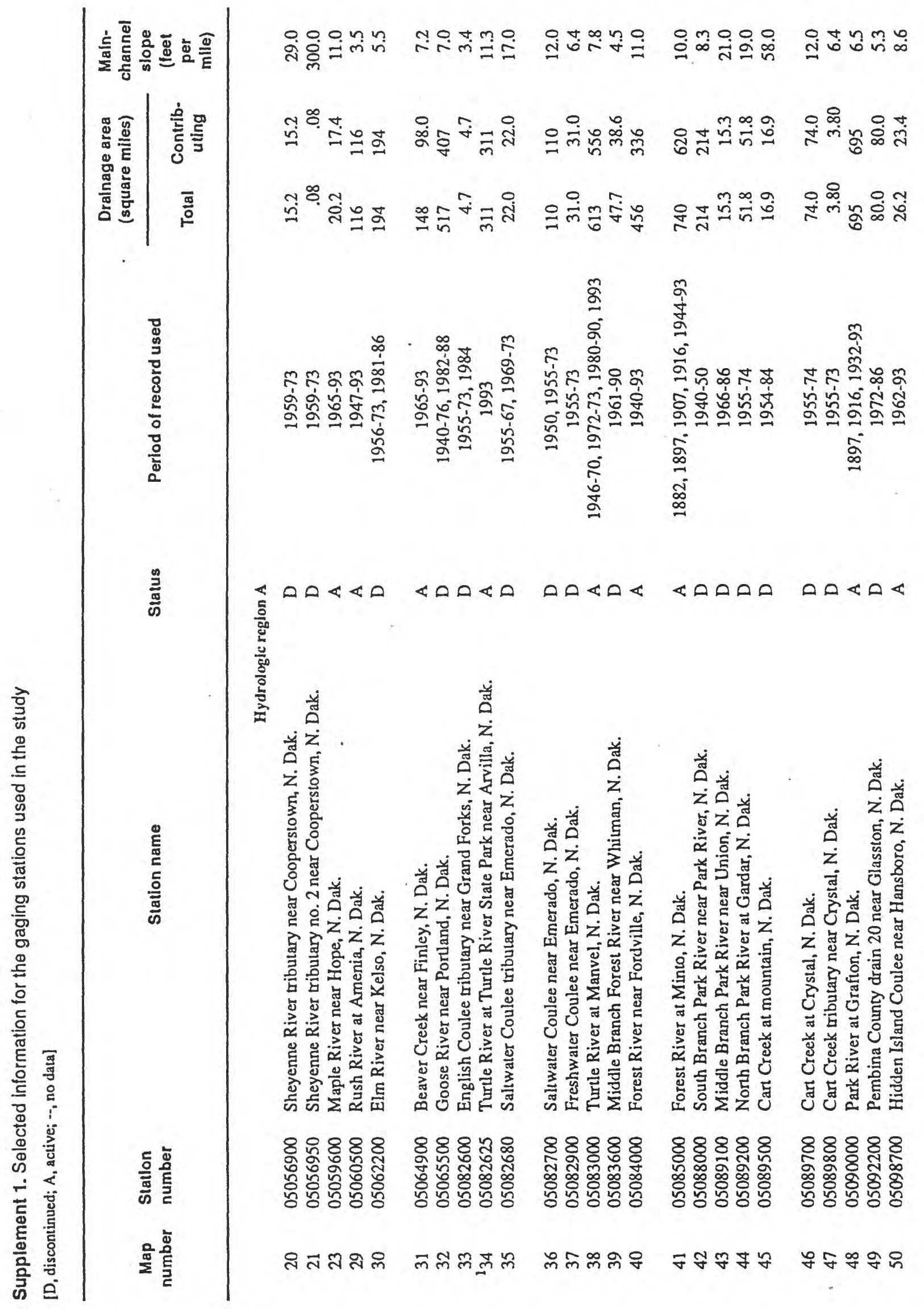




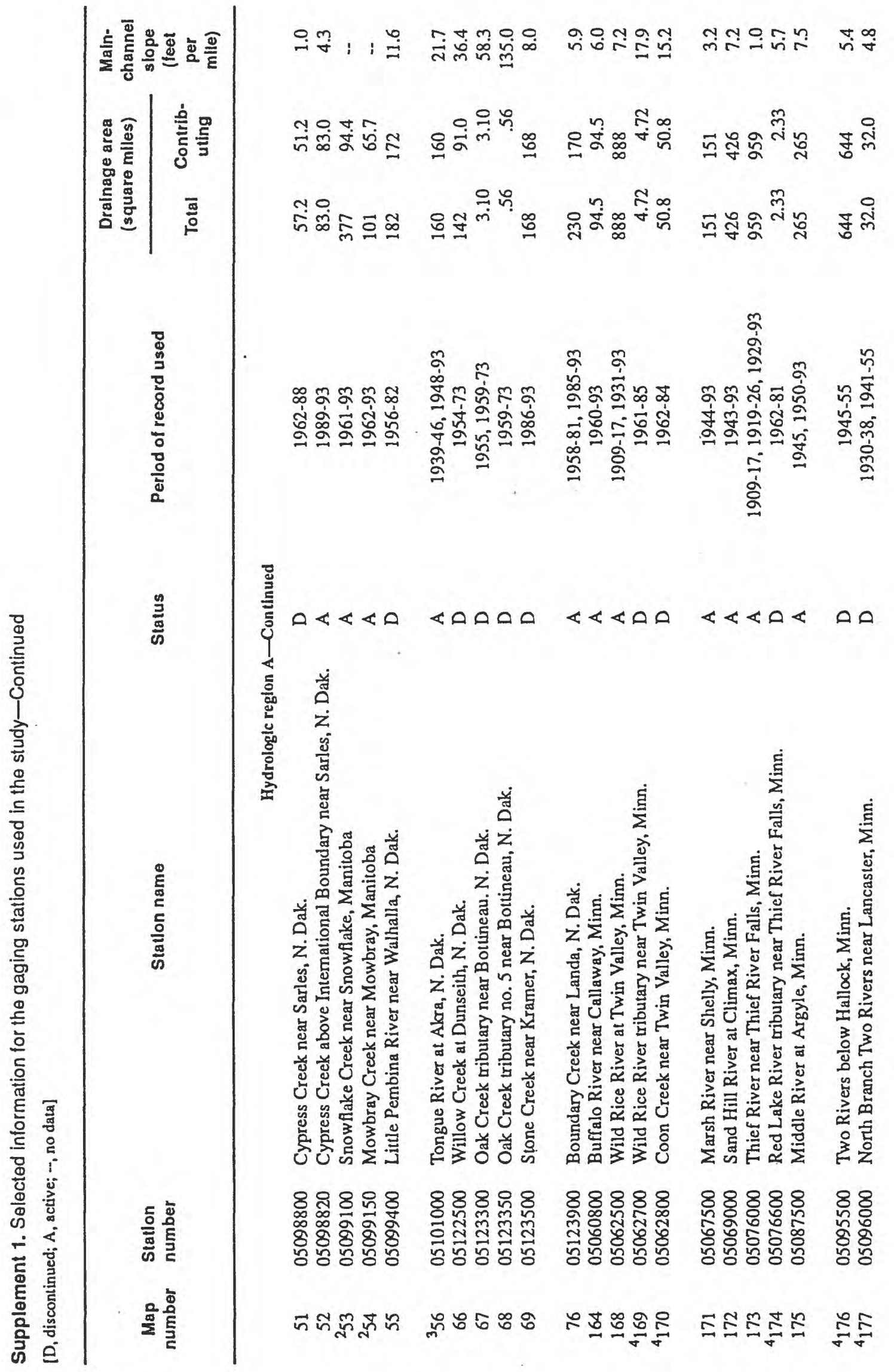




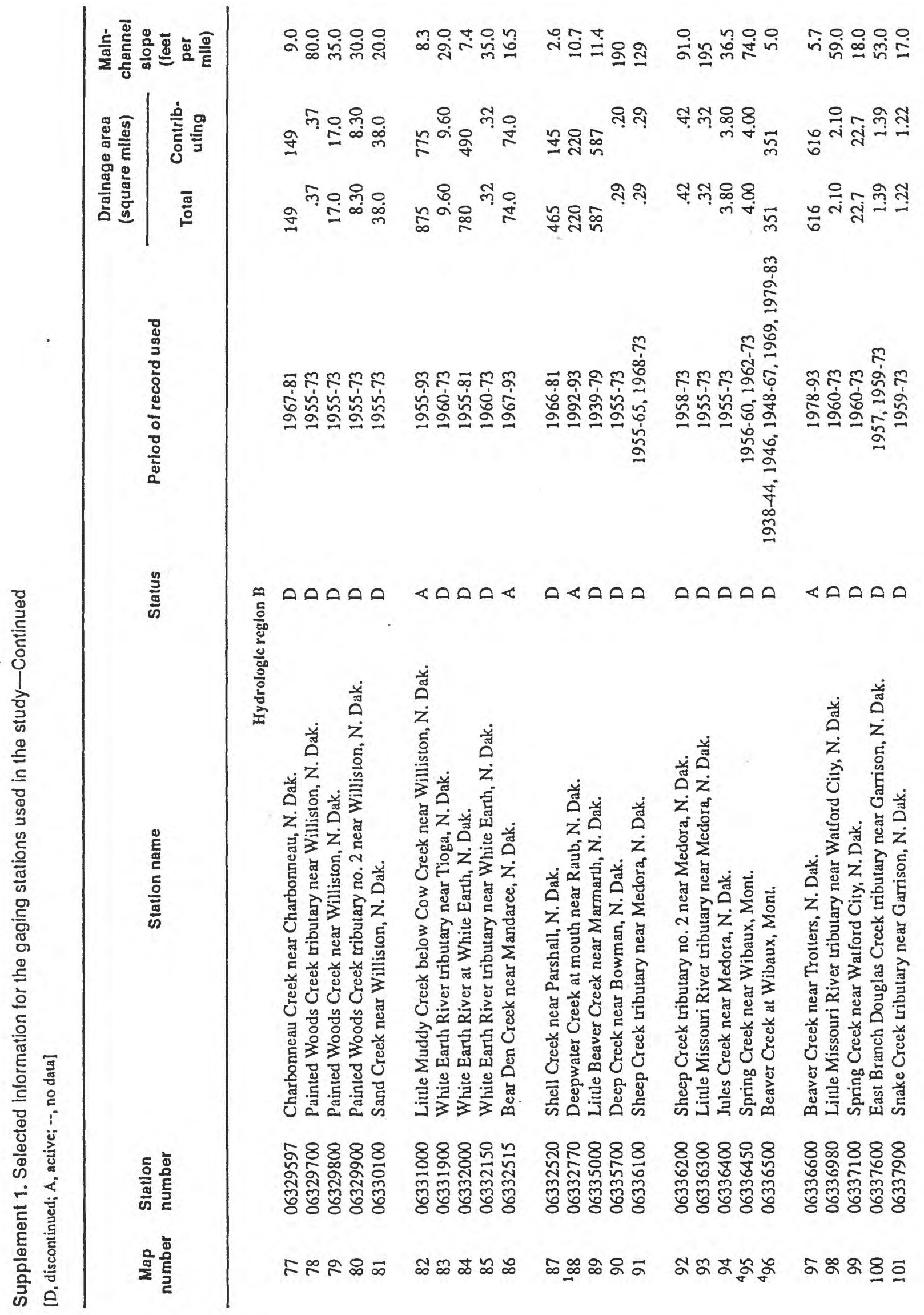




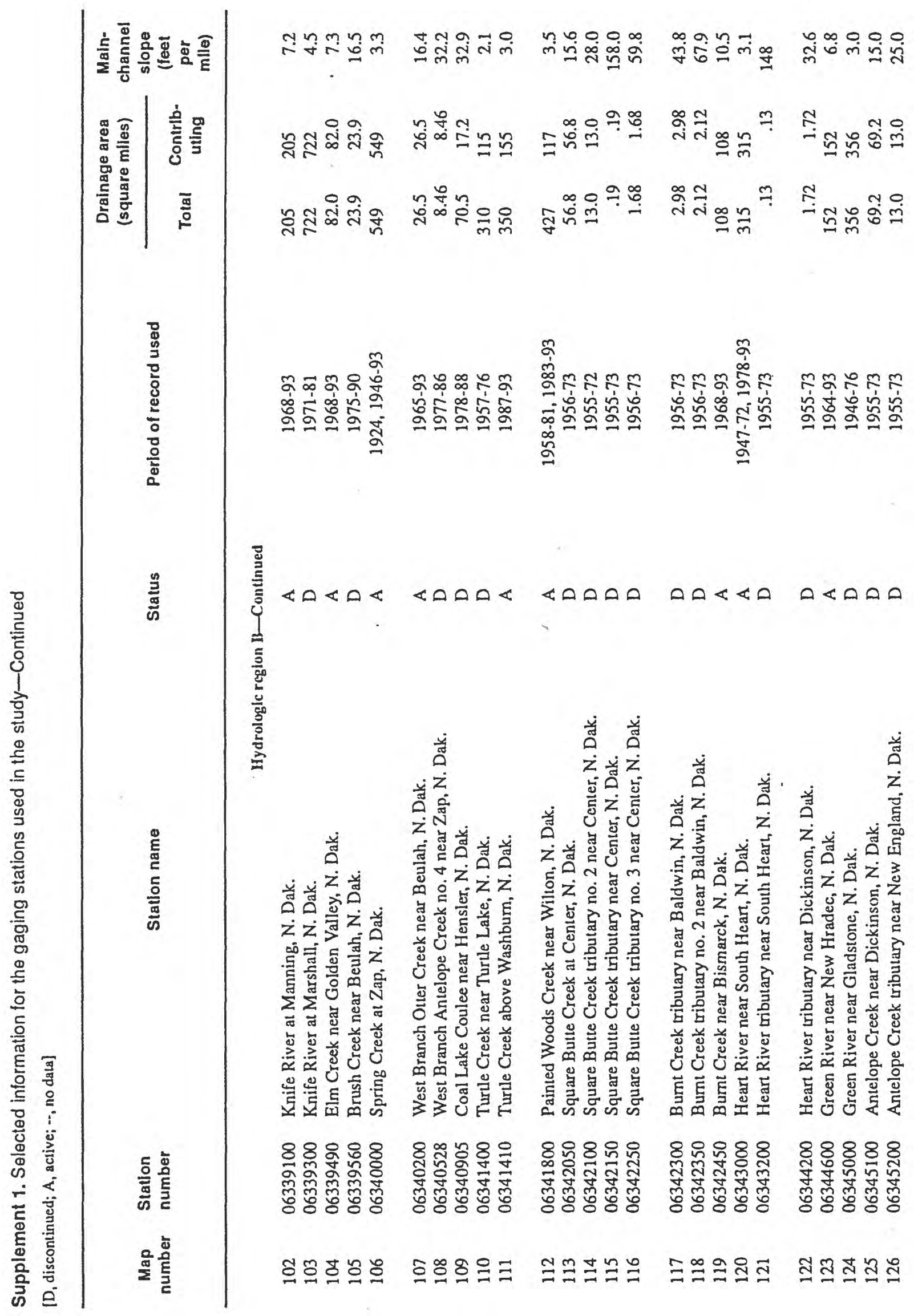




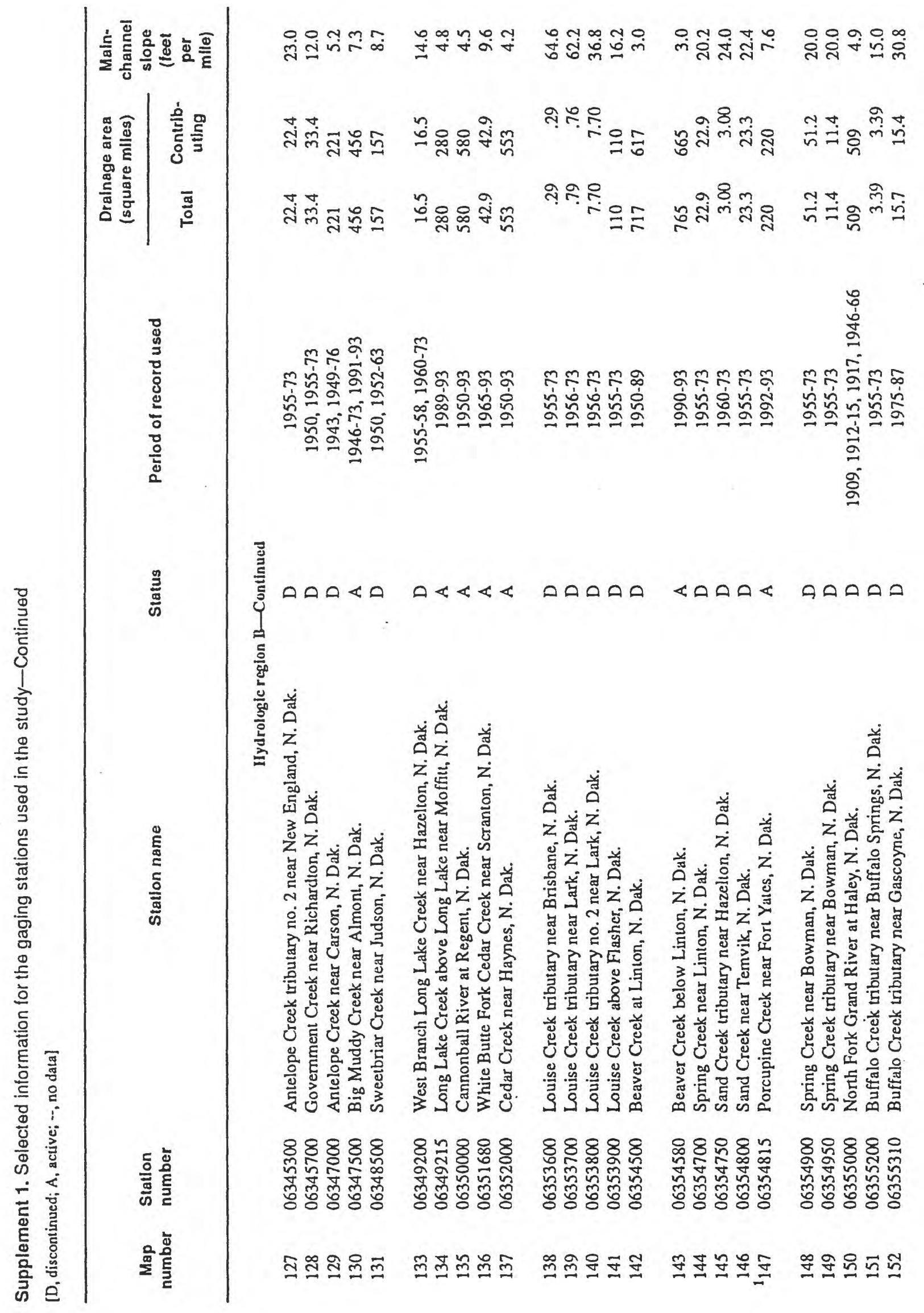




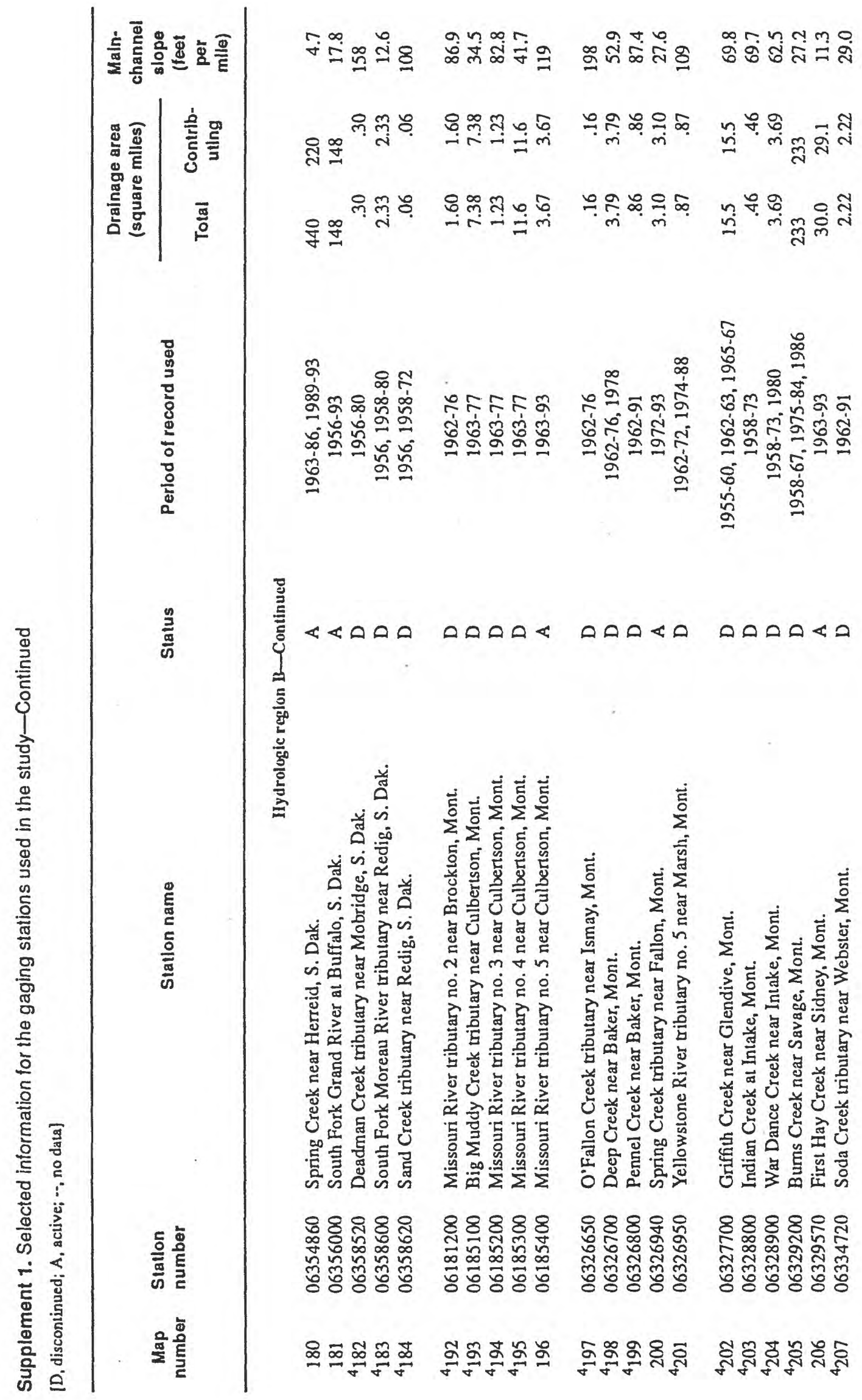




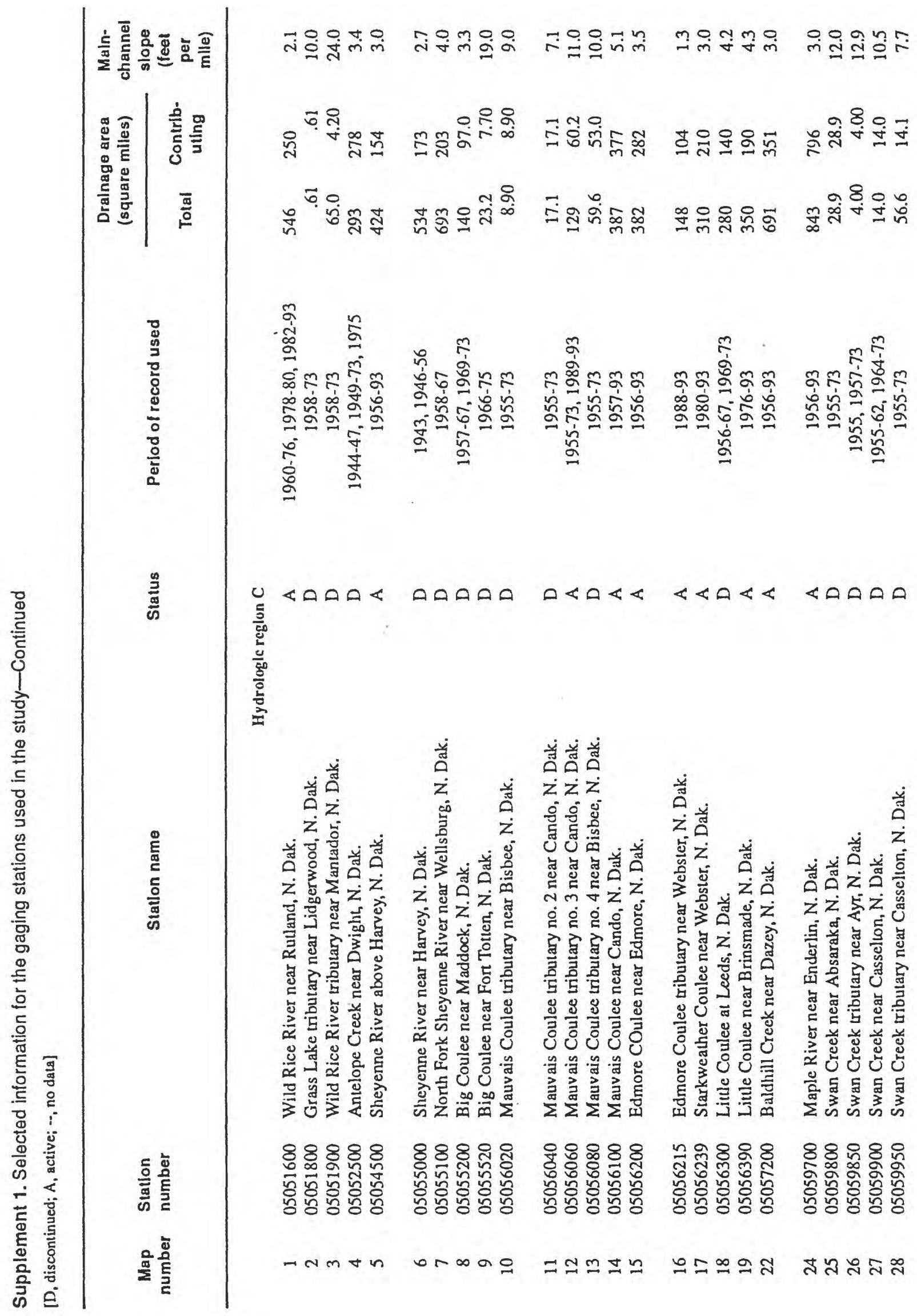




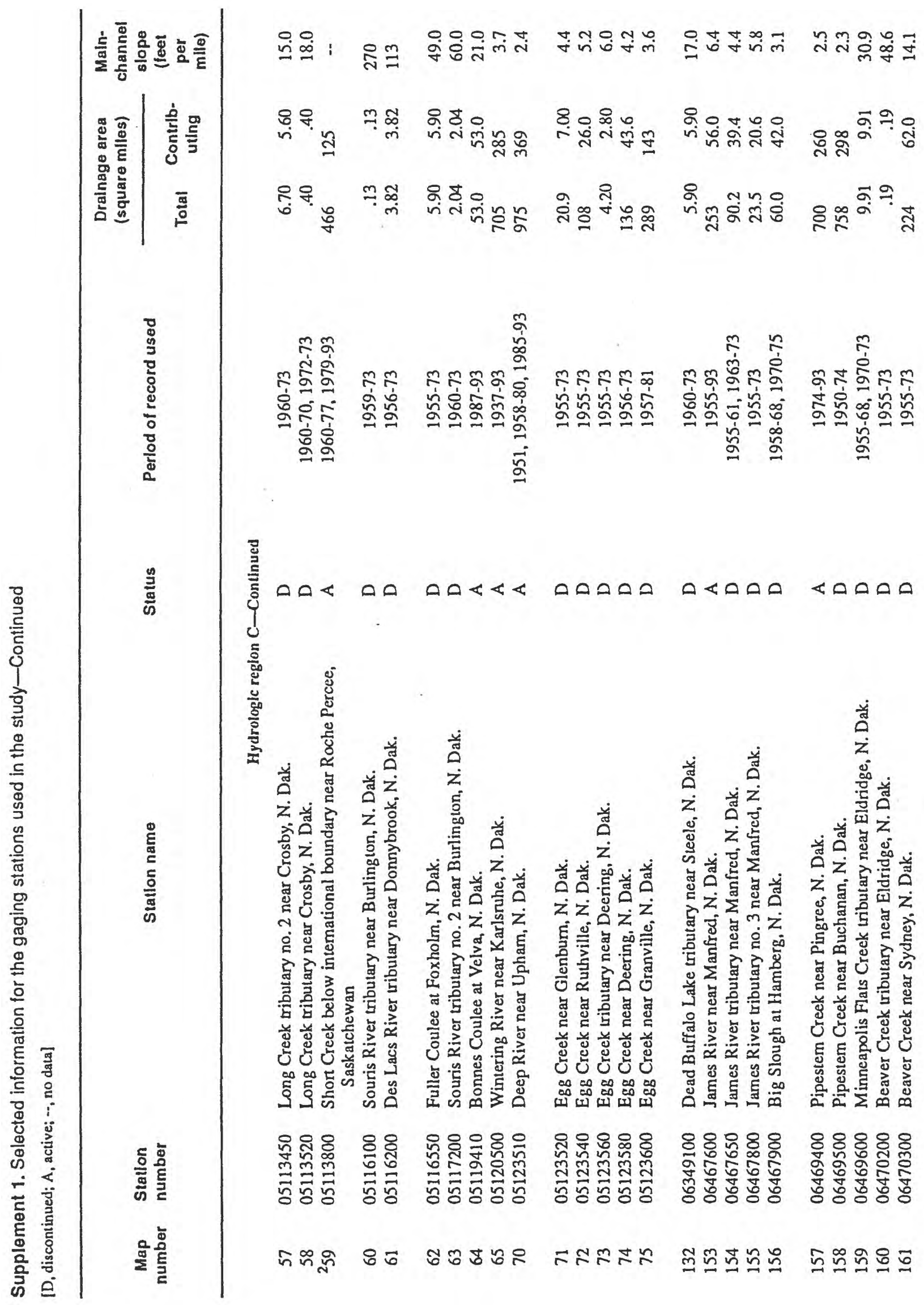




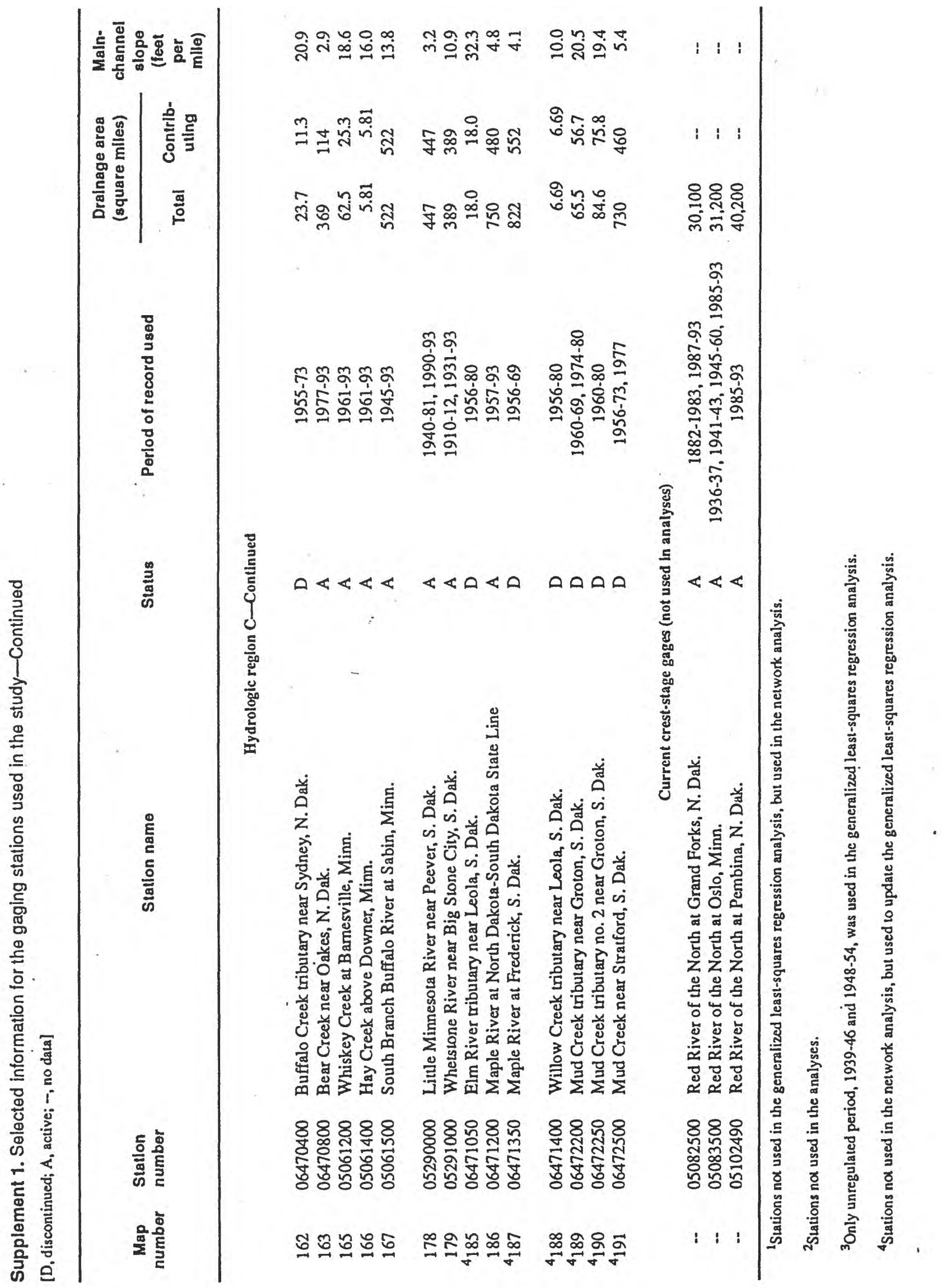

